(C) 2016 Elsevier B.V. This manuscript version is made available under the CC-BY-NC-ND 4.0 license

http://creativecommons.org/licenses/by-nc-nd/4.0/

\title{
Bank Fragility and Contagion: Evidence from the bank CDS market
}

\author{
Laura Ballester \\ (Laura.Ballester@uv.es) \\ University of Valencia, Valencia, Spain \\ Barbara Casu \\ (b.casu@city.ac.uk) \\ Cass Business School, City University London, UK \\ Ana González-Urteaga \\ (ana.gonzalezu@unavarra.es) \\ Public University of Navarre, Pamplona, Spain
}

This version: 18 December 2015

\begin{abstract}
Understanding how contagion works among financial institutions is a top priority for regulators and policy makers who aim to foster financial stability and to prevent financial crises. Using bank credit default swap (CDS) data, we provide a framework for the evaluation of contagion among banks in different countries and regions during a period of prolonged financial distress. We measure contagion in terms of return spillovers, following a Generalized VAR (GVAR) approach. In addition, we propose an innovative framework to distinguish between two types of contagion: systematic (linked to global factors), and idiosyncratic (linked to bank specific factors). We find evidence of both types of contagion, although the spillover dynamics changed over time. Our measure of systematic contagion is always greater than the idiosyncratic component, thus highlighting the importance of common factors in the propagation of risk spillovers. This indicates that international linkages among banking markets are central to the transmission of shocks.
\end{abstract}

Keywords: Credit Default Swaps, Contagion, GVAR, Spillover Indices, Financial Stability

JEL classification: G01, G21, C58 


\section{Introduction}

The turmoil that hit in the world's financial systems in the summer of 2007 has spurred a new debate on bank fragility and contagion. The concept of bank fragility generally refers to increased bank risk taking, leading to higher probability of default. To evaluate bank fragility regulators have traditionally employed bank balance sheet data; although more recently market signals are considered a useful complement to supervisors' traditional accounting information (Gropp et al., 2006). ${ }^{1}$ In financial markets, the propensity for bank-specific risks to spillover to other banks and then to the rest of the economy is often seen as contagion (Allen and Gale, 2000). Understanding how contagion works among financial institutions is currently a top priority for regulators and policy makers who need put in place frameworks for the prevention of financial crises. In addition, the recent eurozone sovereign debt crisis highlighted the importance of cross-border linkages in transmitting local conditions across national borders (Tonzer, 2015), as well as the bank and sovereign risk feedback loops (Acharya et al, 2014; De Bruyckere et al, 2013).

In this paper we evaluate the dynamics of international bank risk transmission and present an empirical method to measure contagion. More specifically, in this analysis contagion relates to the notion that events in one bank/country/portfolio spillover to another bank/country/portfolio through banks' cross-border linkages. We therefore use the terms contagion and spillovers as synonyms, and we define contagion as the spillover effect occurring following a shock. In this setting, for contagion to occur, it needs a trigger or a shock, which amplifies the interdependence or co-movement across variables. Our aim is to shed some light on the potential triggers of contagion in banking markets as well as the channels through which contagion occurs. In line with recent literature, we use the credit default swap (CDS) spreads of major international banks as an indicator of bank credit risk. ${ }^{2} \mathrm{CDS}$ spreads have a number of advantages in proxing for credit risk, including a more accurate

\footnotetext{
${ }^{1}$ As proxies of bank fragility, empirical studies use measures of bank insolvency risk, either based on accounting data (the z-scores) or on market data (using variations of the Merton Distance-to-Default models). ${ }^{2}$ A CDS is essentially an insurance contract against a credit event of a specific reference entity. The CDS spread is the periodic rate that a protection buyer pays on the notional amount to the protection seller for transferring the risk of a credit event for some period. Since late 2008, the CDS market has attracted considerable attention and CDS are considered a good proxy for bank riskiness and default probability. For a survey of the literature on CDS, see Augustin et al. (2014). is:pe:
} 
measurement of default risk and higher liquidity (Blanco et al., 2005; Longstaff et al., 2005; Zhang et al., 2009; Yang and Zhou, 2013). Despite these characteristics, the use of CDS data on financial institutions is fairly recent and it came to prominence only as a consequence of the global financial crisis (Stulz, 2010; Eichengreen et al., 2012).

We estimate contagion following a generalized vector autoregressive framework (GVAR) approach (Diebold and Yilmaz, 2012). GVAR is a VAR-based spillover index particularly suited for the investigation of systems of highly interdependent variables. The methodology allows us to identify the dynamics of the interactions over time and to examine both total and directional spillovers. In addition, we propose an innovative framework to distinguish between systematic and idiosyncratic contagion. To this end, we use Principal Component Analysis (PCA) to extract the common factors underlying the correlations among the CDS returns series of individual banks over the sample period. In our setup, systematic contagion captures the spillover effects due to changes in global factors that affect all banks, whereas idiosyncratic contagion measures the spillover effects caused by changes in bank fundamentals. This decomposition allows us to assess to what extent the increase in bank fragility over the crises period was driven by deteriorating bank fundamentals and increased bank-specific risk taking or whether it reflected decline in global economic and financial conditions that affected all banks as an asset class.

We find evidence of contagion in banking markets, documented by an increase in comovements in CDS returns and confirmed by the results of the GVAR estimations. Contagion came in different waves, with the financial and eurozone crises being distinct episodes with different spillover dynamics. Our results suggest that international linkages among banking markets are central to the transmission of shocks. Our measure of systematic contagion is always greater than the idiosyncratic component, thus highlighting the importance of common factors in the propagation of risk spillovers.

We contribute to the literature in several ways. We bring together the literature on financial contagion and the literature on systematic risk to provide a better understanding of how contagion works in the banking sector. As a novel contribution of the paper, we provide evidence of the time variation of the transmission of credit risk at different stages of the prolonged global crisis by analysing contagion in US and European banking markets during the period January 2004 to March 
2013. We do so in a rolling framework, which enables us to analyse the evolution of contagion over time and during a number of "phases" of market instability. We then put forward an interpretation of how contagion spread, by identifying spillover channels among banking markets. By proposing a novel framework for the identification of systematic and idiosyncratic contagion, we also contribute to the literature that develops measures of financial contagion.

The remainder of the paper is organised as follows. Section 2 presents a review of the literature; Section 3 describes the data and Section 4 presents some preliminary analysis. Section 5 discusses the methodological approach. Section 6 presents the results while section 7 provides some robustness checks. Section 8 reports the results of some additional analysis and Section 9 concludes.

\section{Literature review}

The global financial crisis and the subsequent eurozone crisis highlighted the importance of risk spillovers, or contagion, across international banking and financial markets. Although a very intuitive concept, contagion is difficult to define and measure empirically. This has lead to various definitions and a large body of literature. A common approach to measure contagion is the analysis of correlation coefficients across markets or assets returns and an increase in correlation is seen as evidence of contagion (Forbes and Rigobon, 2002; Corsetti et al., 2005; Broto and Perez-Quiros, 2015). However, financial institutions are highly interconnected through a network composed of the interbank market, the payment system, the financial markets and so on. Similarly, economies are interconnected through financial and trade linkages. Interconnectedness describes situations when financial distress in one institution (country) significantly increases the probability of financial distress in other institutions (countries). The globalization of trade and markets has strengthened these linkages or interconnections, which are also described as spillovers channels of interdependence. When two markets exhibit a high degree of co-movement during stable periods, and these co-movements do not increase significantly after a shock, then it is interdependence rather than contagion (Forbes and Rigobon, 2002). However, increased co-movements heighten the risk that financial distress originating in a few institutions can spread to many others and ultimately impact upon the real economy (Yang and Zhou, 2013). 
In the first instance, contagion can be defined as the transmission of shocks over and above what is expected by the interdependence described above. Dornbusch et al. (2000), Kaminsky et al. (2003), Bae et al. (2003) and Longstaff (2010), among others, define contagion as an episode in which there is a significant increase in cross-market linkages when a shock occurs. In banking markets, contagion can be seen as a negative externality triggered by one institution in distress that affects other market participants. This initial trigger effect needs to be of abnormal speed, strength and scope to cause contagion, which can therefore be seen as the extreme amplification of spillover effects (Alter and Beyer, 2014).

Our contribution builds upon this latter strand of the literature and we define contagion as the spillover effect that follows a shock in a region/portfolio to other regions/portfolios. By proposing an innovative framework to distinguish between systematic and idiosyncratic contagion, we also contribute to the strand of the literature that focuses on the development of methods to evaluate contagion. Pericoli and Sbracia (2003) review different definitions and related measures of contagion, including changes in the probability of currency crises; volatility spillovers (commonly based on the estimation of multivariate GARCH type models); Markov-switching models to test for jumps between multiple equilibria; correlation or co-movements in financial markets and changes in the transmission mechanism, that is when a country-specific shock becomes global. All methodologies have limitations and a number of caveats often apply. More recently, a growing body of the literature has focused on sovereign contagion within the eurozone (see, among others, Caceres et al, 2010; Beirne and Fratzscher, 2013; Alter and Beyer, 2014; Caporin et al, 2015) or on the bank/sovereign risk spillovers (De Bruyckere et al, 2013; Acharya et al, 2014). Our study also complements this strand of the literature and contributes to the understanding of the cross-border channel of bank risk spillovers (Cetorelli and Goldberg, 2011; Degryse et al, 2010; Tonzer, 2015).

\section{Data}

\subsection{The Dataset}

To identify the transmission mechanism of credit risk among banking sectors, we collected daily CDS spreads from the Thomson Datastream database provided by CMA New York, for all 
European and US banks with actively traded CDS over the period January 2004 to March $2013 .{ }^{3}$ For the purpose of our analysis, we selected only those banks with actively traded CDS and exclude those banks that trade too infrequently. Our sample covers over $90 \%$ of banks with traded CDS available in the CMA database and is composed of 55 large banks, headquartered in 15 countries. ${ }^{4}$ Our sample is therefore larger than those used in previous studies; for example Eichengreen et al. (2012) have a sample of 45 banks and Yang and Zhou (2013) of 43 banks as they include only the largest financial institutions in a smaller number of countries. Table 1 illustrates the sample banks, the available number of observations and the total assets value for each bank. More specifically, our sample is composed of 122,984 (unbalanced) panel observations for 2,407 days.

Following Jorion and Zhang (2007) and Eichengreen et al. (2012), among others, we select 5year CDS quotes, since these contracts are generally considered the most liquid and constitute the majority of the entire CDS market. The CDS spread indicates the 5-year CDS premium mid expressed in basis points.

The sample period covers almost a decade $(2004-2013){ }^{5}$ This relatively long time period allows us to investigate a more stable period, the global financial crisis period and the European sovereign debt crisis period. Note that the indication of the reference period as "pre-crisis", "global financial crisis" and "eurozone debt crisis" is only an approximation for ease of discussion. We do not impose specific time periods, as the estimations are carried out on a rolling window framework.

\section{$<$ Insert Table 1 around here $>$}

\footnotetext{
${ }^{3}$ While daily data are subject to more noise compared to weekly and monthly data, there are also some advantages: daily data provide more observation points and, therefore enhances the estimation efficiency (Elyasiani et al., 2015). In addition, daily data better captures short-lived co-movements and spillover effects (Eun and Shim, 1989; Hamao et al., 1990; De Santis and Gerard, 1998). Mayordomo et al. (2014) conclude that among the six most widely used CDS data bases, CMA is the leading data source.

${ }^{4} \mathrm{CDS}$ trading activity is heterogeneous among market participants. Chen et al. (2011) present data on market composition and trading dynamics of global CDS transactions and report that trade frequency in single-name CDS was on average relatively low (less than once a day), with market activity dropping off quickly after the top set of traded names. Notably, the financial sector reference entities include the largest share of the actively traded CDS. For the empirical analysis, we exclude only those banks that trade too infrequently.

${ }^{5}$ Although data on CDS spreads are available from January 2003, only a very small number of banks (around $18 \%$ of the banks in the sample) traded in CDS during 2003; the majority of banks in our sample started to take part in CDS activities after 2004. Our sample covers over $90 \%$ of all banks trading CDS in the CMA database.
} 


\subsection{CDS Returns}

The main difficulty in constructing CDS returns is that there is no time series data on actual transaction prices for a specific default swap contract. To overcome this issue, we follow the intuitive framework proposed by Berndt and Obreja (2010) and use daily CDS spreads to calculate CDS returns, using a strategy that replicates the payoff of the contract. More specifically, we construct excess returns on a synthetic defaultable bond from CDS spreads' data. ${ }^{6}$ This way of constructing the CDS returns entails that a positive (negative) change in the CDS spread implies a negative (positive) CDS return. One additional advantage of using CDS returns is that it allows us to obtain stationary returns series.

\section{Preliminary Analysis}

\subsection{Pair-wise correlations}

The first step to understand contagion is to explore the pair-wise correlations between the CDS returns for the banks in the sample. As we are interested in the level of interconnectedness between markets, we classify banks in the sample according to their country of origin and build equally weighted portfolios of CDS returns to analyse their pair-wise correlations. To do this, we compute the daily country CDS return as the daily average CDS return of all the banks in a country. Country CDS return portfolios correlations are reported in Table $2 .{ }^{7}$ In general terms, we observe a high correlation level ( 0.40 on average) between banks CDS returns portfolios. We interpret it as a preliminary sign of contagion between bank credit markets. The portfolios that present higher than average correlation coefficients are the UK (0.53), the Netherlands (0.52), Italy (0.50), Germany (0.50), Switzerland (0.50), France (0.48) and Spain (0.46).

\footnotetext{
${ }^{6}$ This is a way of overcoming the fact that we cannot compute the return on a CDS initially as it is priced at zero, and because CDS spreads reflect the at-market spread of a new contract. See Appendix A for methodological details.

${ }^{7}$ For ease of exposition, we do not present the pair-wise correlation 55x55 matrix among individual banks CDS. Note that our final objective is to analyze contagion between markets, not between banks. We have nevertheless estimated the pair-wise correlations at the bank level. The results (available upon request) show the expected high interconnectedness among banks within the same country.
} 


\section{$<$ Insert Table 2 around here $>$}

The portfolio of UK banks exhibits the highest correlation with the Netherlands (0.81), followed by Germany (0.73), Italy (0.67) and France $(0.66)$. The correlation between the Netherlands and Switzerland is also high (0.78). These results indicate links between banks inside and outside the euro area. Credit risk interconnectedness is high among euro area banks, for example the Netherlands presents a high correlation with Germany (0.70), Italy (0.68) and France (0.65). On the other hand, the portfolio composed of Greek banks displays the lowest correlation (on average) of the sample (0.10). Finally, the portfolio of US banks presents a correlation with some European countries (for example, Germany, Italy, Netherlands, Switzerland and UK), although the values are lower than expected.

\subsection{Principal Component Analysis}

The high pair-wise correlations summarized in Table 2 indicate high commonality, and thus are often considered a preliminary indicator of contagion. The next step in our analysis is to apply principal component analysis (PCA) to extract the common patterns underlying the correlations among the CDS returns of individual banks. In the first instance, PCA provides us with a measure of the cross-market co-movements around the sample period. If the PCA reveals a significant increase in co-movements, this can be considered a further indication that that contagion has occurred.

In addition, PCA also allows us to decompose the individual bank CDS returns series in two non-observable components: a common and a residual component. This step allows us to decompose each bank's CDS returns into a systematic return, related to common factors, and an idiosyncratic component, that is the part of the CDS return that is not due to commonality.

Let $Y$ be the $T \times k$ CDS returns data matrix, where $T$ is the sample size and $k$ is the number of banks considered in the analysis. We project the data matrix on a $d$-dimensional plane of the form

$$
Y=P C \cdot W^{\prime}+v
$$


where the columns of the $k \times d$ matrix $W$ are $d$ eigenvectors corresponding to the largest $d$ eigenvalues of the correlation matrix $Y Y^{\prime} / T$, the columns of the $T \times d$ matrix $P C$ are the first $d$ principal components, while the resulting innovations are gathered in the columns of the $T \times k$ matrix $v$. In addition to that, PCA provides us with a measure of the percentage of variance explained by each principal component, which is computed as the ratio between the $d$ eigenvalues divided by the sum of all eigenvalues. A significant increase in this measure can be considered as an indicator of contagion.

As discussed above, the use of the common factors on all banks, the matrix $P C$, also enables us to extract the residual component for each bank by using the following regression:

$$
Y_{i}=\alpha_{i}+\beta_{i} \cdot P C+\varepsilon_{i}, i=1, \ldots, k
$$

This approach allows us to decompose each bank's CDS return into a systematic component (due to common factors that affect to all banks), $\alpha_{i}+\beta_{i} \cdot P C$, and a idiosyncratic component, $\varepsilon_{i}$, linked to the bank's fundamentals. This way, we obtain the systematic and idiosyncratic CDS returns for each individual bank.

\section{$<$ Insert Figure 1 about here $>$}

Figure 1 plots the time evolution of the proportion of variance explained by the first four principal components ${ }^{8}$ of bank CDS returns series. ${ }^{9}$ The analysis is performed over the entire sample period, using 200-day rolling windows. It shows that the contribution of common factors to the total variation in CDS returns changes considerably throughout the sample period. Before mid-2007, it

\footnotetext{
${ }^{8}$ The fifth principal component individually explains very little, between $2.5 \%$ and $4.8 \%$ of the variance through the rolling windows. By looking at the eigenvalues, we could potentially choose a higher number of principal components, which have a value higher than one. However, as the values of subsequent components are very close to one, we base the rolling PCA on the first four principal components. The full set of results is not shown, but these are available upon request.

${ }^{9}$ In order to check the potential presence of serial correlation in bank CDS returns correlation matrix we have filtered for autocorrelation. The results are robust and available upon request.
} 
varied between $10 \%$ and $40 \%$ (with an increasing trend over time). On average, in stable periods, bank CDS returns exhibit a limited amount of co-movement. The first four factors explain on average the $33 \%$ of the total variance of the returns, thus suggesting that during stable periods banks' credit risk is mainly linked to fundamentals and not driven by global macroeconomic factors.

The picture changes after the onset of the sub-prime crisis in July 2007. The co-movements in CDS returns increase significantly, fluctuating between $40 \%$ and $70 \%$. After July 2007 , the contribution of the first four components doubled and the percentage of total variance explained by the four components became, on average the $44 \%, 50 \%, 56 \%$ and $60 \%$ respectively. These results indicate that common factors play an important role in bank CDS markets during periods of financial distress. It is possible to identify significant events in financial markets' recent years and observe the corresponding increase in co-movement in CDS returns.

The importance of common factors increased to extraordinary levels between the outbreak of the subprime crisis and the rescue of Bear Stearns, possibly reflecting markets' perceptions of increased credit risk. In the period between January 2007 and March 2008, the portion of variance explained by the first four components jumped from $30 \%$ to $63 \%$. During this period we observe three main peaks: the first one in early August 2007, when co-movement increased quickly (up to 58\%). ${ }^{10}$ The second peak is in January $2008^{11}$, when co-movement increased to $62 \%$; the third peak in March 2008 (at the time of the Bear Stearns troubles) when co-movement in CDS returns increased to 64\%. Following the Bearn Stearns episode, the percentage of variance explained by common components remained high, at 50-60\%. The increase in co-movement became even more evident after Lehman Brothers' failure in September 2008. Further increases in co-movement were related to episodes of the eurozone crisis. For example, in May 2010, at the time of the first Greek bailout, we observe the highest share of explained variance accounted by principal components: it reached $73 \%$, and remained very high until February 2011. On October 27, 2011, we can see a peak of $61 \%$, at the time of the second Greek bailout. A peak of 61\% was then reached on May 16, 2012, amid speculations of a

\footnotetext{
${ }^{10}$ In August 2007, some of the largest equity hedge funds started to report unprecedented losses. See Table B.1 in Appendix B for a timeline of key events.

${ }^{11}$ Specifically, this peak was on January 25, 2008, January 25, 2008, one day after the announcement of the largest drop in 25 years of US home sales and the first house price decrease in several years.
} 
Greek exit from the eurozone. Table B.1 in the Appendix B reports a timeline of key events during the global financial and eurozone crises.

In summary, the results of the PCA indicate that there is a significant amount of commonality in CDS returns across all the 55 banks, which can be interpreted as an indicator of contagion occurring over the sample period. These results are consistent with the idea that during periods of international financial crises, correlations between assets and markets are higher and this is often a key element in the underestimation of risk in stress periods.

To understand the sources of commonality, we examine the weight vector associated with each principal component. To do so, and taking into the account the difficulty of looking at the PCs of each rolling window, we first consider the findings obtained for the whole sample period. In the first $P C$, the highest factor loadings are positive and associated with large European banks (by total assets). We interpret this component as a value-weighted market portfolio of European banks. In the second PC the highest factor loadings are negative and associated with US banks. This component can be interpreted as an area component that distinguishes European banks (with positive weights), and US banks (with negative weights). In the third $P C$, Scandinavian banks are identified, with positive and large weights. These are banks with low CDS spreads. Finally, the fourth component is related to midsized banks in Europe. These are mainly banks from euro-peripheral countries, with positive weights and high CDS spread levels, on average. Hence, we can interpret this fourth PC component as banks from countries most affected by the sovereign debt crisis.

In addition, we also analyse the findings over time. While the results are generally in line with those reported above, when we consider the period January 2004 to July 2007, only the first two PC are important and they can be interpreted as above. During the global financial crisis (July 2007 to September 2009), the second PC captures the differences between banks inside and outside the eurozone, while US banks are gathered in the third PC. Finally, in the last period (October 2009 to March 2013), the second $P C$ is again related to the US area, while the third $P C$ isolates the difficulties that Greek banks were experiencing, in contrast to the good performance of US financial institutions.

\subsection{Building CDS Portfolios}


The use of portfolios provides an efficient way to summarize all the information included in individual bank CDS returns, with the advantage of smoothing the noise in the data, mainly due to transitory shocks in individual institutions. The examination of the weight vectors associated with each principal component has indicated differences between banks in the US, in Europe and within the eurozone. We build upon these results and distinguish between banks headquartered in the socalled GIPS countries (Greece, Italy, Portugal and Spain), other countries in the eurozone, European countries outside the eurozone and the US. ${ }^{12}$

Based on this allocation, we build four equally weighted portfolios, using average CDS data for each bank headquartered in a country within a specific geographical area. The first portfolio consists of banks headquartered in Greece, Italy, Portugal and Spain (GIPS countries); we define this portfolio as euro-peripheral. The second portfolio consists of banks headquartered in Austria, Belgium, France, Germany and the Netherlands; we label this portfolio as euro-core. The third portfolio comprises banks from European countries but outside the eurozone (Denmark, Norway, Sweden, Switzerland and the UK); we label this portfolio non-euro. Finally, our fourth portfolio consists of US banks (simply labelled as US).

The CDS portfolios are computed following a two-step procedure. First, average CDS data are calculated at the country level. The estimation of the average of CDSs for all available banks in a country allows us to circumvent the problem of unbalanced portfolios. Next, portfolios CDS data are calculated as the average CDS data for the countries within a specific portfolio. This allows us to obtain CDS portfolios that reflect the average bank credit risk in a specific portfolio.

\section{$<$ Insert Figure 2 about here $>$ \\ $<$ Insert Table 3 about here $>$}

\footnotetext{
${ }^{12}$ Although not an official definition, the distinction between core (Germany, Austria, the Netherlands, Belgium, Finland and France) and periphery (Italy, Spain, Portugal, Ireland and Greece) within the eurozone has become established in the academic and policy literature since the onset of the eurozone crisis.
} 
Figure 2 illustrates the daily time evolution of CDS spreads and returns series for the four portfolios; descriptive statistics are reported in Table $3 .{ }^{13}$ Prior to July 2007, CDS spreads were relatively stable, at around 16 bps (and this is fairly homogeneous). By July 2007, the extent of the subprime mortgage crisis was becoming apparent; with a sharp increase in mortgage delinquencies and a subsequent decrease in house prices. It can be easily seen that from July 2007 CDS spread started to increase dramatically, both in level and volatility, mainly for US banks. October 2009, on the other hand, is considered the beginning of the eurozone crisis, although signs of instability appeared much earlier. In March 2009 CDS spreads peaked at over 216 bps for euro-peripheral countries' banks; at 274 bps for euro-core; at 228 bps for non-euro and 338 bps for US banks respectively. Note that all the banks in the sample experienced positive CDS returns (on average) during the pre-crisis period, whereas throughout the global financial crisis returns became negative on average. This may suggest that during periods of instability CDS spreads are not fully explained by banks' credit risk (default component), but are also driven by the overall market situation (common global component). For US banks, negative average CDS returns were around 50\% lower than CDS returns for European banks. Outside the US, countries whose banks were the most affected by the global financial crisis were Belgium, Greece and Spain. With hindsight, this can be seen as a prelude to the trouble their banks faced in more recent times.

In the months following the peak of the sub-prime crisis, the level of CDS spreads for US and European banks began to fall, but it remained higher then in the pre-crisis period. In 2009, substantial differences between US and European banks started to emerge. US banks' CDS spreads peaked in March 2009, at over 338 bps. The trend then reverted, with US banks' CDS spreads reaching a minimum in December 2009 and remaining stable thereafter. Indeed, in the period 2009-2013, US banks' CDS spreads stabilised at values below those seen previously but higher than pre-crisis period values. In Europe, however, the recovery phase was short-lived; bank CDS spreads increased

\footnotetext{
${ }^{13}$ The division of the sample into three sub-periods is an approximation for ease of discussion. Since both CDS spreads' evolution (Figure 2) and the PCA analysis indicate significant differences around these dates, it is convenient to discuss the sub-periods when analysing the summary statistics. Note however, this has no implication for the study of contagion in the next step, as the estimations are carried out on a 200-day rolling window.
} 
gradually during the last quarter of 2009 and displayed record peaks in November 2011 and then again in May 2012, mainly following the Greek crisis and speculations of a Greek exit from the eurozone. It is during this period that the differences between US and European banks CDS spreads became more evident, thus indicating that, while European banks were badly affected by the subprime crisis, US banks were relatively immune to eurozone banks' troubles. Indeed, US banks are the only banks with positive average CDS returns during the most recent part of our sample period.

From October 2009, differences also become apparent among European banks' portfolios. Specifically, banks from euro-peripheral countries exhibit larger increase in CDS spreads, driven mainly by Greek banks (up to a peak of 4,191 bps), Portuguese banks (with a peak of 1,484 bps) and, to a lesser degree, Spanish (peak 770 bps), Belgian (peak 709 bps) and Italian banks (peak 695 bps). These exceptionally high values are evidently linked to the sovereign debt crisis. ${ }^{14}$ In contrast, CDS spreads for German and UK banks remained stable during the same time period. In addition, banks from countries outside the eurozone showed, on average, lower levels and volatility compared to the CDS spread curve for their eurozone counterparts.

\section{GVAR methodology}

Having established high co-movement in bank CDS returns, the next step is to evaluate if contagion occurred. We estimate return spillover effects following the Generalized Vector Autoregressive framework (GVAR) methodology developed by Diebold and Yilmaz (2009; 2012), which is a VAR-based spillover index particularly suited for the investigation of systems of highly interdependent variables. The methodology not only allows for the identification of the directional lead-lag effects between two variables (spillover effect), but also allows us to determine which effect dominates in a bivariate or multiple effects situation (net indices). This allows for the identification of net transmitters and receivers of spillovers. In addition, GVAR assigns a numerical value (between 0 and 100 in the case of the total index; and between -100 and 100 in the case of net indices) to the spillovers across portfolios, thus providing measures that indicate the degree of interaction between

\footnotetext{
${ }^{14} \mathrm{~A}$ detailed discussion of the events that might have caused the peaks is outside the remit of this paper. Appendix B, Table B.1 offers a timeline of the key events of the crises.
} 
the variables. Finally, the estimations can be carried out in a rolling window framework, therefore allowing for the analysis of spillover effects over time. Given the prolonged period of turbulence in international banking markets, this enables us to understand better the dynamics of international risk transmission.

Spillovers are measured from a particular variance decomposition associated with an $\mathrm{N}$-variable vector autoregression framework, which allow us to parse the forecast error variances of each variable into parts, which are attributable to the various system shocks. The main advantage of this approach is that it eliminates the possible dependence of the empirical results on the ordering of the variables, in contrast to the traditional Cholesky factorization. ${ }^{15}$

More specifically, this approach consists of two steps. First, we consider a covariance stationary $N$-variable $\operatorname{VAR}(p)$

$$
x_{t}=\sum_{i=1}^{p} \phi_{i} x_{t-i}+\varepsilon_{t}
$$

where $\varepsilon \sim(0, \Sigma)$ is a vector of independently and identically distributed disturbances and $x_{t}$ denotes a $N$-variable vector of CDS returns. In particular, since the analysis is performed twice, $x_{t}$ will be first the systematic and second the idiosyncratic CDS returns of the four portfolios previously built.

Next, we calculate the specific variance decompositions of the GVAR methodology. To do so we first rewrite the $\operatorname{VAR}(p)$ model as a moving average representation $x_{t}=\sum_{i=0}^{\infty} A_{i} \varepsilon_{t-i}$, where the $N \times N$ coefficient matrices are estimated by $A_{i}=\phi_{1} A_{i-1}+\phi_{2} A_{i-2}+\cdots+\phi_{p} A_{i-p}$, with $A_{0}$ being the identity matrix and $A_{i}=0$ for $i<0 .{ }^{16}$ Now, the variance shares defined as the fractions of the $H$ step-ahead error variances in forecasting $x_{i}$ that are due to shocks to $x_{j}, H=1,2, \ldots$, are given by

\footnotetext{
${ }^{15}$ It is a well-known that traditional variance decomposition schemes associated with a VAR based on Cholesky factorization suffer from the problem that results are dependent on the ordering of the variables. Following the GVAR approach, this problem is circumvented by exploiting the generalized VAR framework of Koop et al. (1996) and Pesaran and Shin (1998), among others.

${ }^{16}$ For a detailed explanation of the VAR methodology see Lütkepohl (1990) and Lütkepohl (2005).
} 


$$
\theta_{j \rightarrow i}^{G}(H)=\frac{\sigma_{j j}^{-1} \sum_{h=0}^{H-1}\left(e_{i}^{\prime} A_{h} e_{j}\right)^{2}}{\sum_{h=0}^{H-1}\left(e_{i}^{\prime} A_{h} \Sigma A_{h}^{\prime} e_{i}\right)}, \text { for } i, j=1,2, \ldots, N
$$

where $\mathrm{H}$ can only take finite values, $\sigma_{j j}$ is the standard deviation of the error term for the $j^{\text {th }}$ equation, i.e. the squared root of the diagonal elements of the variance-covariance matrix $\Sigma$ and $e_{i}$ is the vector with one as the $i^{\text {th }}$ element and zeros otherwise. This particular generalized variance decomposition eliminates the dependence of the spillover effects on the ordering of the variables. Nevertheless, as the shocks to each variable are not orthogonalized, the row sum of the variance decomposition is not equal to 1 . Thus, each entry of the variance decomposition matrix can be normalized by the row sum as

$$
\tilde{\theta}_{j \rightarrow i}^{G}(H)=\frac{\theta_{j \rightarrow i}^{G}(H)}{\sum_{j=1}^{N} \theta_{j \rightarrow i}^{G}(H)} \times 100, \text { for } i, j=1,2, \ldots, N
$$

where the multiplication by 100 is just to have it in percentage terms. Note that, by construction $\sum_{j=1}^{N} \widetilde{\theta}_{j \rightarrow i}^{G}(H)=100$ and $\sum_{i, j=1}^{N} \tilde{\theta}_{j \rightarrow i}^{G}(H)=N \times 100$.

In this framework, each element of the normalized decomposition matrix shows the degree (the percentage) of variation in CDS returns of portfolio $i$ that is due to shocks (innovations) in CDS returns of portfolio $j$. This indicator is our measure of contagion; it captures the return spillover effect to portfolio i's deriving from unexpected shocks in portfolio $j$ 's. It takes higher values as the intensity of the contagion effect increases. In the case of no spillovers from one series to the other, the indicator is equal to zero.

Using the above normalized variance contributions, we can then construct some additional spillover measures, which indicate the degree of interaction between the variables. The total return spillover index measures the contribution of spillovers of return shocks across all $N$ series to the total forecast error variance and is given by: 


$$
T S^{G}(H)=\frac{\sum_{\substack{i, j=1 \\ i \neq j}}^{N} \widetilde{\theta}_{j \rightarrow i}^{G}(H)}{N}
$$

It indicates on average the percentage of the forecast error variance in all the series that comes from spillovers (from contagion due to shocks). In other words, it captures the average level of crossmarket spillovers.

The GVAR approach enables us also to evaluate the direction of the spillover effects, which is crucial in a spillover analysis. The net directional return spillover indices measure the spillover transmitted by portfolio $i$ to all others

$$
N D S_{i \rightarrow a l l}^{G}(H)=\sum_{\substack{j=1 \\ i \neq j}}^{N} \tilde{\theta}_{i \rightarrow j}^{G}(H)-\sum_{\substack{j=1 \\ j \neq i}}^{N} \tilde{\theta}_{j \rightarrow i}^{G}(H), \text { for } i=1,2, \ldots, N
$$

This is the difference between the spillover effects transmitted by portfolio $i$ to all other portfolios and those received by $i$ from all other portfolios. In other words, when multiple spillover effects are found among the portfolios, we are able to determine which portfolio leads as transmitter (receiver) of contagion to (from) all the others. If the spillover transmitted from $i$ is higher (lower) than the spillover received by $i$, the index NDS will be positive (negative), and thus portfolio $i$ can be seen as a transmitter (receiver) of contagion to (from) all other.

Similarly, the GVAR enables us to identify the transmitter or receiver of contagion between each pair of portfolios. The net pairwise return spillover indices between series $i$ and $j$ are defined as

$$
N P S_{i \rightarrow j}^{G}(H)=\tilde{\theta}_{i \rightarrow j}^{G}(H)-\tilde{\theta}_{j \rightarrow i}^{G}(H), \text { for } i, j=1,2, \ldots, N
$$

This is the difference between spillover effects transmitted from $i$ to $j$ and those transmitted from $j$ to $i$. Hence, it is positive (negative) when the impact of $i$ 's shocks is higher (lower) than vice versa, indicating that portfolio $i$ is net transmitter (receiver) of contagion to (from) portfolio $j$. 


\section{Empirical results}

We generate GVAR spillover measures using 200-day rolling samples and assess the variation over time via the corresponding time series of spillover indices. The model is estimated twice, once for the systematic and once for the idiosyncratic CDS returns of the four portfolios built previously (euro-peripheral; euro-core; non-euro and US). This yields estimates of systematic and idiosyncratic contagion. Systematic contagion indicates the presence of spillovers among the portfolios of systematic CDS returns while idiosyncratic contagion indicates the presence of spillovers among the portfolios of idiosyncratic CDS returns. In this context, our measure of systematic contagion captures the spillover effects due to changes in global factors that affects all banks' credit risk whereas idiosyncratic contagion measures the spillover effects caused by changes in bank-specific factors.

At each window, the lag $p$ of the GVAR model is determined using the likelihood ratio test, which confirms that $p$ varies over time. ${ }^{17}$ To choose the forecast horizon of ten days $(H=10)$ we compute at each window the total return spillover index for $H$ varying from 1 to 16 . The results show that the index is sensitive to the choice of the forecast horizon for low values of $H$, but in general it is stabilized for $H=10$. This is the forecasting horizon commonly used in similar studies (see for example Diebold and Yilmaz, 2012).

\section{$<$ Insert Figure 3 here $>$}

Figures 3 to 5 illustrate the evolution over time of the different return spillover measures, corresponding to the total return spillover index of systematic contagion (TSI-SC - in black in the Figures) and to the total return spillover index of idiosyncratic contagion (TSI-IC - in grey in the Figures). This part of the analysis aims to measure the cross-border spillovers in banking markets.

The time dependent TSI-SC illustrated in Figure 3 reveals high levels of contagion across markets, especially after the onset of the global financial crisis on July 2007. Prior to the credit crunch, the TSI-SC was around 44\%, while the TSI-IC was only around $10 \%$.

\footnotetext{
${ }^{17}$ The Akaike information criterion does lead in some cases to higher values, but this criterion tends to overestimate the number of lags.
} 
In July 2007, with the onset of the sub-prime crisis, systematic contagion started to increase: it climbed from $44 \%$ to $74 \%$ in the following months (the maximum of the TSI-SC throughout the whole sample period) and it remained at around $60 \%$ for the rest of the sample period. This indicates a high level of interconnectedness across bank CDS markets, due to global factors affecting all banks. Idiosyncratic contagion also increased (to 17\%) in July 2007, but the peak only lasted a few days and then it decreased to previous levels. As the sub-prime crisis turned into the global financial crisis, we find strong evidence of systematic contagion across banking markets. During the global financial crisis period, the idiosyncratic contagion index remains rather low, although it does respond to some key events: for example, it increases in September 2008 (up to 30\%) when Merrill Lynch was sold to Bank of America and Lehman Brothers collapsed.

During the eurozone sovereign debt crisis (2009-2013) idiosyncratic contagion became more pronounced, increasing from $10 \%$ to $21 \%$ on average. Although the TSI-SC remained high $(60 \%)$, it was slightly lower than in the previous sub-period. At the height of the Greek crisis, the TSI-IC increased to $35 \%$, but the systematic component still played an important role of (it reached its third peak during our sample period, at 67\%). During the second half of 2011, the increasing concerns about the worsening of public finances in several eurozone countries, together with the perspective of a Greek exit from the euro area, heightened financial market tensions. This lead to increased fragility of many eurozone banks (Greek, Italian and Spanish banks in particular) and was reflected in an increase in the idiosyncratic component of $40 \%$ (the biggest increase over the whole sample period).

The policy measures implemented by the ECB in October 2011 and February 2012 appeared to have had a positive impact, as they seemed to result into a more benign financial market sentiment in the first half of $2012 .{ }^{18}$ The TSI-SC remained high, fluctuating at around $60 \%$, however, the idiosyncratic component declined significantly after December 2011. Finally, a significant increase in the idiosyncratic spillover index occurred in the period September-December 2012 (over 20\%). One possible explanation is that markets worried about the fate of Spanish banks, as Spain's cost of borrowing increased dramatically.

\footnotetext{
${ }^{18}$ The ECB decided to conduct refinancing operations that significantly extended the horizon at which credit institutions could obtain liquidity from the Eurosystem (for more details see Appendix B).
} 
To summarize, the total return spillover indices vary substantially over time, with higher values during periods of market turbulence. Of the two indices, the total return spillover index of systematic contagion (TSI-SC) is higher than the idiosyncratic total return spillover index (TSI-IC) over the entire sample period, indicating that contagion in banking market is mainly driven by shocks to common factors affecting all banks. However, we have identified a few instances where idiosyncratic shocks have cause spillovers in other banking markets. These seem to be linked to episodes of bank failure (for example, the Lehman Brothers' in September 2008) or increased probability of bank failure, for example in the case of Spanish banks during the last two quarters of 2011.

\subsection{Net Directional Spillovers and Net Pairwise Return Spillovers}

The next step of the analysis is to account for directional information. To this end, we compute the net directional return spillover index, which will enable us to identify the net transmitters and receivers of contagion. The results are illustrated in Figure 4. In addition we compute the net pairwise return spillovers effects between two portfolios and consider the time evolution of the pair-wise relationships: these are summarized in the three sub-periods as above: January 2004 - June 2007; July 2007 - September 2009; October 2009 - March 2013, as shown in Figure 5. ${ }^{19}$

\section{$<$ Insert Figure 4 here $>$ \\ $<$ Insert Figure 5 here $>$}

Looking at Figures 4 and 5, we can see that during the first part of the sample period (January 2004 - July 2007) both systematic and idiosyncratic contagion are present in all portfolios, which indicates that all banks in all countries/portfolios were both at the giving and receiving ends of the net transmissions, with similar magnitudes. The picture changes during the crises period.

\footnotetext{
${ }^{19}$ To summarize the main results, Figure 5 shows only the overall net pairwise return spillovers relationships. The division into the three sub-periods is an approximation for ease of discussion as the GVAR estimations are carried out on a rolling window framework. Graphs relating to the time evolution of net pairwise return indices are not presented to conserve space but are available upon request.
} 
Banks in the US remained positive, in net systematic terms, during the global financial crisis (2007-2009). In July 2007, the net directional return systematic spillovers from US banks were as high as $90 \%$ and were mostly transmitted to banks located in euro-core (45\%) and to a lesser extent to banks in euro-peripheral countries (25\%) and to banks in non-euro countries (18\%). During this period, euro-core countries were the main net systematic receivers of instability, not only from the US, but also from euro-peripheral (15\%) and non-euro (18\%). After this extraordinary impact, systematic contagion declined significantly. The Bear Stearns and Lehman Brothers episodes impacted systematically (both around 10\%) in all other zones. In summary, US banks were a natural net systematic return spillover transmitter during the global financial crisis, while banks in the three other markets/portfolios were net systematic return spillover receivers.

Consistently with the results presented for the total spillover indices, during the financial crisis period we find a limited amount of idiosyncratic contagion. There were some isolated significant events, linked to specific domestic episodes in some European banks. In general, net spillover measures were lower and their impact was more pronounced a year later than systematic contagion. In particular, after Lehman Brothers' default (September 2008) until the end of 2009, banks in europeripheral countries became net idiosyncratic transmitters to the other European portfolios ( $18 \%$ to euro-core and $10 \%$ to non-euro). In addition, euro-core banks not only received idiosyncratic contagion from banks in the euro-peripheral portfolio, but also from the non-euro portfolio, with an impact of 13\% in September 2008.

Moving on to the period of the eurozone sovereign debt crisis, banks in the euro-peripheral portfolio were the net idiosyncratic transmitters (to all other portfolios), particularly from May 2010 (following the first Greek bailout) and with a bigger impact during the second half of 2011. However, the impact of the Greek bailout seems to be stronger for banks in non-euro countries, while banks in euro-core countries were less affected. Similarly, banks in the US are barely responding to eurozone banks' troubles. During this period, banks in euro-core countries we the net systematic transmitters, with the spillovers mostly affecting banks in euro-peripheral countries. During 2013, euro-peripheral banks were receivers of both systematic and idiosyncratic contagion, from euro-core and non-euro banks. Finally, the Cyprus debt crisis on March 19, 2013 caused a significant increase in both 
spillover indices. Following this episode, the indices decreased again, signaling that the immediate risk of a eurozone breakup seemed to have been averted and confidence was slowly recovering.

This part of the analysis illustrates the importance of evaluating the time-varying dimension of risk spillovers as well as the main sources of contagion. The identification of net transmitters and receivers of contagion allows us to build a clear picture of the channels through which contagion occurred. The fact that the systematic component dominates in all the analysis indicates the increased interconnection of global banking markets. International banks are exposed to common shocks through holdings of foreign-issued financial instruments and through foreign lending exposures. Indeed, most large banks had substantial holdings of US-issued financial instruments (particularly asset backed and mortgage backed securities), which contributed to the transmission of risk spillovers. On the other hand, US banks have relatively low holdings of foreign assets, both in terms of government securities and foreign lending, which can potentially explain why they did not appear to receive risk spillovers from European banks during the sovereign debt crisis period.

\section{Robustness tests}

\subsection{A Comparison with Market Indices}

To understand whether our measure of systematic contagion captures the information included in the sovereign CDS spreads for the countries in our sample, we build an index that reflects the average of all sovereign CDS spreads in the sample. We then investigate the trend of this sovereign CDS index over time, focusing specifically around dates when our total return spillover index for systematic contagion (TSI-SC) 'peaked'. This additional analysis allows us to see that the TSI-SC does reflect changes in sovereign CDS, but also incorporates 'other' information. In assessing this comparison, it is necessary to bear in mind that the sovereign CDS spreads indicate an increase in the perceived risk of a country, whereas our measure indicates how this increased risk affects the CDS spreads of other countries. Figure 6 (Panel A, B, C, D and E), illustrates the time evolution of our sovereign CDS index at particular points in time over the sample period. In the second half of 2007, our TSI-SC rose from $44 \%$ to $74 \%$ indicating an increase in systematic contagion. We can see (Figure 
6, Panel A) that prior to June 2007, the sovereign CDS index is stable at around 5bps, increasing significantly thereafter. Interestingly, the increase in the sovereign CDS index precedes of a month the increase in the TSI-SC (20 June 2007 for the CDS index and 30/07/2007 for TSI-SC) but does not reach the same levels. Following the peak in June 2007, the CDS index remains stable (although at higher values) till the end of 2007.

From our main analysis, the TSI-SC increases to $70 \%$ in September 2008. The sovereign CDS index (Figure 6, Panel B) also increases substantially in September 2008, reaching a first peak of 75 bps on October 24, 2008; a second peak of 120 bps on December 8, 2008; and a third of 150 bps on February 25, 2009. During this period, our TSI-SC and the sovereign CDS index reflect similar changes.

The next peak in our TSI-SC index is in May 2010 (67\%). Figure 6, Panel C, illustrates the trend in the average sovereign CDS index as defined above. At the beginning of May 2010 the index was at around 122 bps, with an increasing trend following the first Greek bailout and the downgrade in the rating of the Greek government bonds. It reached 178 bps on 7 May 2010 (an increase of 45.90\%). After this sharp increase, the sovereign CDS index fell to 104 bps on 12 May 2010, and then stabilised at high levels of around $150 \mathrm{bps}$. Again, the sovereign CDS index is consistent with the spillovers identified by the TSI-SC in May 2010.

In March 2012 the sovereign CDS index (Figure 6, Panel D) rises sharply, as a consequence of the extremely high levels of Greece's sovereign CDS spreads (37,030.49 bps). Our average index therefore reflects this rise, prior to the Greek government's decision to discontinue the CDS market on 8 March 2012. This increase is consistent with the trend in the TSI-SC, which also show increases in the first half on 2012. Finally, between July 2012 and March 2013, we observe a slight decrease in the level of systematic contagion that is reflected in a slight reduction in the level of sovereign CDS (Figure 6, Panel E) between September and December 2012. However, although the sovereign CDS index decreases, it remains at exceptionally high levels (over $120 \mathrm{bps).}$

Next, we compare the results obtained in our main analysis concerning the total return spillover index for idiosyncratic contagion (TSI-IC). As, the TSI-IC reflects changes in CDS returns linked to bank fundamentals, we compare it to share prices returns for our portfolios. 
For the purpose of this analysis, we build two stock returns portfolios for the Greek and Spanish banks in our sample to show the average stock returns (Greek Banks Stock Returns Index and Spanish Banks Stock Returns Index). Figure 6, Panel F, illustrates the stock returns for our portfolio of Greek banks in 2010, at around the time of the first Greek bailout. The negative stock returns seem consistent with an increase in the TSI-IC. Next we build a stock returns portfolio for the Spanish banks in our sample. Figure 6, Panel G, illustrates the stock returns for our portfolio of Spanish banks between July 2012 and March 2013, at the time of the increases in the TSI-IC documented in the main analysis. While negative returns seem broadly consistent with increases in the TSI-IC, idiosyncratic contagion does not fully reflect share prices returns. While the index reflects the deterioration of share prices of Greek and Spanish banks, it also captures the extent to which shocks in one bank spillover to other banks - this spillover effect is not fully incorporated in market prices.

\section{$<$ Insert Figure 6 here $>$}

\subsection{Weighted portfolios}

As a robustness check, we repeat the analysis using weighted portfolios (by total assets). Weighted portfolios reflect the average credit risk for a specific area, giving greater weight to larger banks. The time evolution of the spillover indices derived from the use of weighted portfolios is in general similar to the ones obtained with equally weighted portfolios. However, it appears that the use of weighted portfolios overestimates the levels of contagion. Table 4, Panel A summarises the main differences with respect to the original analysis. Results show that the total return spillover index for systematic contagion in the pre-crisis period is higher than in the estimations carried out with equally weighted portfolios. The higher systematic contagion before 2007 is related to the greater spillovers that US banks receive from all the others, specifically after January 2006. The second main difference relates to idiosyncratic contagion; while the general trend is consistent with the previous estimations, it is about $10 \%$ higher during the whole sample period. In addition, it shows a peak of $37.46 \%$ in August 2007, remaining high for several months afterwards. This peak relates to the increment in the idiosyncratic contagion that euro-peripheral banks receive from non-euro and US banks. This spillover effect is absent with equally weighted portfolios. 


\section{$<$ Insert Table 4 here $>$}

\subsection{Excluding the US portfolio}

As a further robustness check, we repeat the analysis using only the portfolios of European banks (the euro-peripheral; euro-core and non-euro portfolios). On average, the exclusion of the US banks portfolio from the analysis does not lead to major differences, in terms of contagion, either systemic or idiosyncratic. However, there are certain differences that indicate the fundamental role of US banks in the transmission of risk spillovers. When we exclude the portfolio of US banks from the analysis, the contagion indices are always lower. In addition, around some key events, the exclusion of US banks leads us to underestimate contagion (see Table 4, Panel B for a summary of the key differences).

For example, at the beginning of the subprime crisis in August of 2007 the systematic spillover is $58.64 \%$ (instead of $74.58 \%$ ). Directional relations between European countries remain consistent with previous analysis; however the key information regarding US banks as causing the increase in systematic contagion is lost. In addition, during the months following the onset of the subprime crisis while systematic contagion remains high, the values are lower compared to the previous analysis $(47.40 \%$ vs. $61.23 \%)$. More importantly, we note that during the eurozone crisis period, the exclusion of the US banks portfolio might lead to a misspecification of the results. This is because the analysis ignores an important part of the common risk factors (systematic ones) affecting all banks. Therefore, the idiosyncratic returns (that is the portion of returns after the common part is removed), not only collect the changes due to changes in the banks fundamentals, but they also have a large part of common contagion (the one relative to the US) contaminating the results. This is particularly important in the latter part of the sample period, where the idiosyncratic component is more important. For example, at the time of the first Greek bailout (May 2010), the idiosyncratic contagion index is only of $7.45 \%$ compared to the $35.01 \%$ obtained from the estimations that included the US portfolio. Similarly, during the second half of 2011 the peak values are around $20 \%$ compared 
to values over $40 \%$ obtained in the original analysis. Directional relations between the different portfolios remain consistent, but their magnitude is diminished.

\section{Contagion within the euro-peripheral portfolio}

Given the severity of the eurozone crisis and the potential effect of contagion, particularly within the eurozone periphery or GIPS countries, we carry out an additional analysis estimating systematic and idiosyncratic contagion among the countries that belong to euro-peripheral portfolio.

One of the key concerns of regulators and policymakers during the first Greek debts crisis was the potential spillover to banks in Spain, Portugal and Italy. ${ }^{20}$ This part of the analysis therefore aims to analyse the effect of the Greek crisis during the period 2009 to 2013 and its spillovers on Italian, Spanish and Portuguese banks. We build four equally weighted portfolios using average CDS data for each bank headquartered in a euro-peripheral country. Similarly to our prior analysis, the estimation of the average of CDS returns for all available banks in a country allows us to circumvent the problem of unbalanced portfolios. This allows us to obtain CDS portfolios that reflect the average bank credit risk in a specific country/portfolio.

As before, we generate GVAR spillover measures using 200-day rolling samples and assess the variation over time via the corresponding time series of spillover indices. The model is estimated twice, once for the systematic and once for idiosyncratic CDS returns of the four countries/portfolios. In the discussion of the results we refer to Greece, Spain, Portugal and Italy as the portfolios including Greek, Spanish, Portuguese and Italian banks.

\section{$<$ Insert Figure 7 here $>$}

Figures 7 to 9 present the time evolution of the different return spillover measures between 2009 and 2013. The total systematic contagion between euro-peripheral countries is rather high during the whole sample period (50.37\% on average) and increasing during 2010 , at the height of the sovereign debt troubles. These results confirm a high level of interconnectedness across bank CDS markets of euro-peripheral countries, mainly due to common factors affecting all banks (particularly

\footnotetext{
${ }^{20} \mathrm{We}$ thank an anonymous referee for suggesting this extension to the analysis.
} 
in 2010). We observe a peak of 72.53\% in May 10, 2010 just 2 days after the second Greek bailout was approved, which indicates that contagion affected systematically all euro-peripheral banks. In the months following this event, the systematic contagion index remained high, at around $61.70 \%$ on average.

\section{$<$ Insert Figure 8 here $>$ \\ $<$ Insert Figure 9 here $>$}

However, the most interesting results are concerning the net indices, which show Greek banks as being net receivers of systematic contagion ( $11.77 \%$ on average) from all other portfolios. This effect is particularly pronounced in the period prior to July 2011, at the time of the second EU rescue package. At this time, Greece received net systematic contagion equal to $23.02 \%$, of which $8.93 \%$ from Italy; 5.01\% from Portugal and 9.07\% Spain.

Consistently with the previous analysis, the total idiosyncratic contagion index displays lower values compared to the systematic index: the average for whole sample is $33.98 \%$. It is possible, however, to identify three distinct phases with high levels of idiosyncratic contagion: during 2010 an average value of $38.22 \%$, with a peak of $50.66 \%$ in April 2010. This corresponds to the Greek government request of an initial loan of $€ 45 \mathrm{bn}$ from the EU and IMF. The second period is mid-2011, with an average value of value of $41.72 \%$ and finally at the end of 2012 , with an average value of $41.48 \%$.

As with the systematic component, the most significant results are the ones related with the net indices, which indicate that Greek banks are also receivers of idiosyncratic contagion from all other banks (5.47\% on average). This effect was especially high prior to January 2011 , with Greece receiving $8.95 \%$ of idiosyncratic contagion (mostly from Spain at $5.95 \%$ ). We can identify Spain as a net transmitter of idiosyncratic contagion in the period June 2011 to January 2012. Spanish banks transmit $20.47 \%$ of idiosyncratic spillovers to all others, with values of $6.7 \%, 8.1 \%$ and $5.5 \%$ to Greece, Italy and Portugal, respectively. 
To sum up, the most surprising result is the role of Greek banks as net receivers of contagion, both systematic and idiosyncratic. This seems to indicate that the difficulties experienced by Greek banks did not spillover to other euro-peripheral banks whereas troubles elsewhere in the europeriphery affected Greek banks and added to their woes.

\section{Conclusion}

This paper provides an evaluation of contagion among banks and banking sectors in different countries and regions during a period of prolonged financial distress. Increased integration in global financial markets strengthened the linkages between banks in different countries. This increased interdependence ultimately resulted in the sub-prime crisis - a problem in a sector of the US financial market - becoming a global financial crisis. Despite a growing literature, the transmission mechanisms of contagion are still not fully understood. Banks are likely to remain vulnerable to episodes of instability and continued stress in the markets.

We find supporting evidence of contagion in banking markets, firstly indicated by an increase in co-movement in CDS returns. This marked increase in commonality should be considered an early warning, alerting authorities to intervene. Contagion came in different waves, from July 2007 onwards, with the financial and eurozone crises being distinct episodes. Indeed, while during the financial crisis contagion was systematic in nature, during the eurozone crisis the idiosyncratic part played an increasing role. The examination of net directional return spillover measures enabled us to identify group of banks in countries that can be seen as net transmitters and receivers of contagion. US banks appear to be net transmitters during the 2007-2009 period. During the eurozone crisis, banks in euro-peripheral countries were net transmitters in terms of idiosyncratic spillovers although eurozone troubles barely affected US banks. Differences in vulnerability to contagion within the Europe and even within the eurozone are remarkable, with the eurozone periphery more exposed to systematic contagion. The analysis of contagion within the euro-periphery portfolio confirms high levels of the systematic contagion index. Greek banks are net receivers of both systematic and idiosyncratic risk spillovers, particularly from Spanish banks. 
Taken together these findings seems to indicate that international linkages among banking markets are important for the transmission of shocks - as the systematic component of the total spillover index is always greater than the idiosyncratic component. However, there are some instances in the recent eurozone crisis where idiosyncratic shocks have cause spillovers in other banking markets. This seems to be linked to episodes of bank failure (for example, the Lehman Brothers' failure in September 2008) or increased risk of bank failure as in the case of Spanish banks during the last two quarters of 2011. 


\section{Acknowledgments}

This paper has been prepared while Laura Ballester and Ana Gonzalez-Urteaga were visiting researchers at Cass Business School, City University London. Laura Ballester and Ana González-Urteaga would like to express their gratitude for the funding received from Fundación Ramón Areces. Ana González-Urteaga acknowledges financial support from ECO2012-34268, ECO2012-35946 and from Cass Business School under the Pump Priming Grant Scheme.

We thank Patrick Augustin; Alejandro Balbás; M. Teresa Corzo; Shubhashis Gangopadhyay; Theoharry Grammatikos; Stuart Hyde; Sergio Mayordomo, David McMillan; Antonio Mele; Phil Molyneux; Alfonso Novales; Antonio Rubia; Yoko Shirasu; Giovanni Urga; John O.S. Wilson and Carlos Zurita for valuable comments and discussions on earlier drafts of this paper. We also thank the participants at FMA, EFMA, BAFA, IFABS, FINEST and Wolpertinger 2013 Conferences; the XIII Iberian-Italian Congress of Financial and Actuarial Mathematics; the XX Finance Forum; the XXI Finance Forum; the XXII International Conference of Money, Banking and Finance and the European Sovereign Debt Crisis Conference for stimulating discussions. 


\section{References}

Acharya, V., Drechsler, I., and Schnabl, P. (2014) 'A Pyrrhic victory? Bank Bailouts and Sovereign Credit Risk' The Journal of Finance, 69(6), 2689-739.

Allen F. and Gale, D. (2000) 'Financial Contagion”, Journal of Political Economy, 108(1), 1-33.

Alter, A., and Beyer, A. (2014) 'The dynamics of Spillover Effects during the European Sovereign Debt Turmoil', Journal of Banking \& Finance, 42, 134-153.

Andernmatten, S. and Brill, F. (2011) Measuring Co-Movements of CDS Premia during the Greek Debt Crisis, Working paper 1104.

Augustin, P., Subrahmanyam, M.G., Tang, D.Y., Wang S.Q. (2014) 'Credit Default Swaps: A Survey Foundations and Trends in Finance', 9(1-2), 1-196.

Bae, K., Karolyi, G. A. and Stulz, R. M. (2003) 'A New Approach to Measuring Financial Contagion', Review of Financial Studies, 16, 717-763.

Beirne, J. and Fratzscher, M. (2013) 'The Pricing of Sovereign Risk and COntagion during the European Sovereign Debt Crisis', Journal of International Money and Finance, 34, 60-82.

Berndt, A. and Obreja, I. (2010) 'Decomposing European CDS Returns', Review of Finance, 14, 189233.

Blanco, R., Brennan, S. and Marsh, I. (2005) 'An empirical analysis of the dynamic relationship between inverstment grade bonds and credit default swaps', The Journal of Finance, 60, 22552281.

Broto, C., Perez-Quiros G. (2015) 'Disentangling contagion among sovereign CDS spreads during the European debt crisis', Journal of Empirical Finance, in press.

Caporin, M., Pelizzon, L., Ravazzolo, F., and Rigobon, R. (2015) Measuring Sovereign Contagion in Europe. SAFE Working Paper No. 103.

Caceres, C., Guzzo, V., Segoviano, M. (2010) Sovereign spreads: global risk aversion, contagion or fundamentals?IMF working paper, WP/10/120.

Cetorelli, N., Goldberg, L.S. (2012) 'Banking globalization and monetary transmission' The Journal of Finance, 67, 1811-1843. 
Chen, K., Fleming, M., Jackson, J., Li, A. and Sarkar, A. (2011) An Analysis of CDS Transactions: Implications for Public Reporting, Staff Report No. 517.

Corsetti, G., Pericoli, M., Sbracia, M. (2005) 'Some contagion, some interdependence: more pitfalls in tests of financial contagion', Journal of International Money and Finance, 24, 1177-1199.

De Bruyckere, V., Gerhardt, M., Schepens, G., and Vander Vennet, R. (2013) 'Bank/Sovereign Risk Spillovers during the European Debt Crisis' Journal of Banking \& Finance, 37, 4793-4809.

Degryse, H.A., Elahi, M.A., Penas, M.F. (2010) 'Cross-border exposures and financial contagion', International Reveviw of Finance, 10, 209-240.

De Santis, G. and Gerard, B. (1998) 'International Asset Pricing and Portfolio Diversification with Time-Varying Risk', The Journal of Finance, 52, 1881-1912.

Diebold, F. and Yilmaz, K. (2012) 'Better to give than to receive: predictive directional measurement of volatility spillovers', International Journal of Forecasting, 28, 57-66.

Diebold, F. X. and Yilmaz, K. (2009) 'Measuring financial asset return and volatility spillovers, with application to global equity markets', Economic Journal, 119, 158-171.

Dornbusch, R., Park, Y. C. and Cleassen, S. (2000) 'Contagion: Understanding How It Spreads', The World Bank Research Observer, 15, 177-197.

Eichengreen, B., Mody, A., Nedeljkovic, M. and Sarno, L. (2012) 'How the Subprime Crisis went global: Evidence from bank credit default swap spreads', Journal of International Money and Finance, 31, 1299-1318.

Elyasiani, E., Kalotychou, E., Staikouras, S. and Zhao, G. (2015) 'Return and Volatility Spillover among Banks and Insurers: Evidence from Pre-Crisis and Crisis Periods', Journal of Financial Services Research, in press.

Eun, C. and Shim, S. (1989) 'International Transmission of stock market movements', Journal of Financial and Quantitative Analysis, 24, 241-256.

Forbes, R. and Rigobon, R. (2002) 'No Contagion, Only Interdependence: Measuring Stock Market Commovements', Journal of Finance, 57, 2223-2261. 
Gentile, M. and Giordano, L. (2013) 'Financial contagion during Lehman default and sovereign debt crisis. An empirical analysis on Euro area bond and equity markets', Journal of Financial Management, Markets and Institutions, 2, 197-224.

Gropp, R., Vesala, J., Vulpes, G. (2006) 'Equity and bond market signals as leading indicators of bank fragility', Journal of Money, Credit and Banking, 38, 399-428.

Hamao, Y., Masulis, R. and Ng, V. (1990) 'Correlations in price changes and volatility across international stock markets', Review of Financial Studies, 3, 281-308.

Jorion, P. and Zhang, G. (2007) 'Good and bad credit contagion: Evidence from credit default swaps', Journal of Banking and Finance, 84, 860-883.

Kaminsky, G. L., Reinhart, C. M. and Vegh, C. A. (2003) 'The unholy trinity of financial contagion', The Journal of Economic Perspectives, 17, 51-74.

Koop, G., Pesaran, M. H. and Potter, S. M. (1996) 'Impulse response analysis in non-linear multivariate models', Journal of Econometrics, 74, 119-147.

Longstaff, F., Mithal, S. and Nies, E. (2005) 'Corporate yield spreads: Default risk or Liquidity? New evidences from the credit default swap market', Journal of Finance, 60, 2213-2253.

Longstaff, F. A. (2010) 'The Subprime Credit Crisis and Contagion in Financial Markets', Journal of Financial Economics, 97, 436-450.

Lütkepohl, H. (1990) 'Asymptotic distributions of impulse response functions and forecast error variance decompositions of vector autoregressive models', The Review of Economics and Statistics, 72, 116-125.

Lütkepohl, H. (2005) 'New introduction to multiple time series analysis'. Springer, Berlin.

Mayordomo, S., Peña, J. I. and Schwartz, E. S. (2014) 'Are All Credit Default Swap Databases Equal?', European Financial Management, 20, 677-713.

Pericoli, M. and Sbracia, M. (2003) 'A Primer on Financial Contagion', Journal of Economic Surveys, 17, 571-608.

Pesaran, M. H. and Shin, Y. (1998) 'Generalized impulse response analysis in linear multivariate models', Economics Letters, 58, 17-29. 
Stulz, R. (2010) 'Credit default swaps and the credit crisis', Journal of Economic Perspectives, 24, 7392.

Tonzer, L. (2015) 'Cross-border interbank networks, banking risk and contagion', Journal of Financial Stability, 18, 9-32.

Yang, J. and Zhou, Y. (2013) 'Credit risk Spillovers Among Financial Institutions around the Global Credit Crisis: Firm Level Evidence', Management Science, 59, 2343-2359.

Zhang, B., Zhou, H. and Zhu, H. (2009) 'Explaining credit default swaps spreads with the equity volatility jump risks of individual firms', Review of Financial Studies, 22, 5099-5131. 


\section{Appendix A. Estimation of banks' CDS returns}

CDS returns are computed following Berndt and Obreja (2010). The authors assert that returns on CDS reward for the exposure to the company's default risk and compute CDS returns considering a portfolio that combines a long position in a T-year par defaultable bond issued by firm $\mathrm{i}$ and a short position in a T-year par riskless bond. This way, the computed return can be thought of as the excess return on a synthetic defaultable bond created by being long in a par-valued riskless bond and short the CDS on the same notional.

Therefore, the daily CDS return is given by

$$
r_{C D S, t}=-\Delta C D S_{t}(T) \times A_{t}(T)=-\Delta C D S_{t}(T) \frac{1}{4} \sum_{j=1}^{4 T} \delta\left(t, \frac{j}{4}\right) q\left(t, \frac{j}{4}\right)
$$

where $\Delta C D S_{t}(T)$ is the daily change in the CDS spreads with $T$ maturity and $A_{t}(T)$ is the value of a defaultable quarterly annuity over the next $T$ years. We denote the risk-free discount factor for day $t$ and $s$ years out as $\delta(t, s)$ and it is fitted from Datastream Euro and US zero curves. Assuming a constant risk-neutral default intensity $\lambda$ for each bank, the risk-neutral survival probability of the bank over the next $s$ years can be written as $q(t, s)=e^{-\lambda(t-s)}$. As a consequence, $\lambda$ can be computed directly from observed CDS spreads by $\lambda=4 \log \left(1+\frac{C D S}{4 L}\right)$, which can be used to calculate the annuity and hence the CDS return. $L$ denotes the risk-neutral expected fraction of notional lost in the event of default. It is fixed at $60 \%$. 


\section{Appendix B. A timeline of the crises with selected key events}

\section{Table B.1}

\section{Calendar of key events}

This table shows a chronology of selected key events occurred during the recent global financial crisis and the eurozone debt crisis.

\begin{tabular}{|c|c|}
\hline Date & Key Events \\
\hline July 18,2007 & $\begin{array}{l}\text { Bear Stearns discloses that High-Grade Structured Credit and Enhanced Leveraged } \\
\text { Funds had lost nearly all of their value amid a rapid decline in the market for subprime } \\
\text { mortgages. }\end{array}$ \\
\hline July 19, 2007 & $\begin{array}{l}\text { Dow Jones Industrial Average Index (DJIA) closes above 14,000 for the first time in its } \\
\text { history. }\end{array}$ \\
\hline July 26, 2007 & $\begin{array}{l}\text { Wall Street lost } 2.26 \% \text {, the London Stock Exchange, } 3.15 \% \text {, the Frankfurt Stock } \\
\text { Exchange, } 2.39 \% \text {, the Paris Bourse } 2.78 \% \text {. }\end{array}$ \\
\hline August 7, 2007 & $\begin{array}{l}\text { Numerous quantitative long/short equity hedge funds began experiencing } \\
\text { unprecedented losses as a result of liquidations by some managers eager to access cash } \\
\text { during the liquidity crisis. This is often considered the starting date of the worldwide } \\
\text { "credit crunch". }\end{array}$ \\
\hline August 9, 2007 & $\begin{array}{l}\text { French investment bank BNP Paribas suspends three investment funds that invested in } \\
\text { subprime mortgage debt, due to a "complete evaporation of liquidity" in the market. } \\
\text { This announcement compels the intervention of the European Central Bank (ECB), } \\
\text { pumping €95bn into the European banking market. }\end{array}$ \\
\hline August 10, 2007 & $\begin{array}{l}\text { Central banks coordinate efforts to increase liquidity for first time since the aftermath of } \\
\text { the September } 11,2001 \text { terrorist attacks. The Federal Reserve (FED) injects a combined } \\
\$ 43 \text { bn, the ECB } \$ 214.6 \mathrm{bn} \text {, and the Bank of Japan } \$ 8.4 \mathrm{bn} \text {. }\end{array}$ \\
\hline August 16, 2007 & $\begin{array}{l}\text { Countrywide Financial Corporation, the biggest US mortgage lender, narrowly avoids } \\
\text { bankruptcy by taking out an emergency loan of } \$ 11 \text { bn from a group of banks. }\end{array}$ \\
\hline August 17, 2007 & $\begin{array}{l}\text { The FED cuts the discount rate from } 6.25 \% \text { to } 5.75 \% \text {, in an attempt to stabilize } \\
\text { financial markets. }\end{array}$ \\
\hline January 24,2008 & $\begin{array}{l}\text { The National Association of Realtors (NAR) announces the largest drop in home sales } \\
\text { in } 25 \text { years, and the first price decline in many years. }\end{array}$ \\
\hline March 10, 2008 & $\begin{array}{l}\text { DJIA at the lowest level since October } 2006 \text {, falling more than } 20 \% \text { from its peak just } \\
\text { five months prior. }\end{array}$ \\
\hline March 16, 2008 & Bear Stearns is acquired by JP Morgan, in a deal supported by the FED. \\
\hline September 7, 2008 & The FED takeover of Fannie Mae and Freddie Mac, effectively nationalizing them. \\
\hline September 15, 2008 & $\begin{array}{l}\text { Merrill Lynch is sold to Bank of America amidst fears of a liquidity crisis and Lehman } \\
\text { Brothers collapse. }\end{array}$ \\
\hline September 17,2008 & FED lends $\$ 85$ bn to AIG to avoid bankruptcy. \\
\hline September 19, 2008 & $\begin{array}{l}\text { Paulson financial rescue plan ( } \$ 700 \mathrm{bn} \text { emergency bailout through the purchase of toxic } \\
\text { assets) is unveiled after a volatile week in stock and debt markets. }\end{array}$ \\
\hline September 25, 2008 & Washington Mutual is seized by the FDIC and its banking assets sold to JP Morgan. \\
\hline January 18, 2009 & $\begin{array}{l}\text { The Danish Parliament agrees to a financial package worth } \$ 17.6 \mathrm{bn} \text {. This marks the } \\
\text { beginning of the Eurozone debt crisis. }\end{array}$ \\
\hline February 27, 2009 & $\begin{array}{l}\text { The two-month period to the end of February } 2009 \text { is the worst start to a year in the } \\
\text { history of the S\&P } 500(-18.62 \%) \text {. }\end{array}$ \\
\hline March 2, 2009 & DJIA drops more than $50 \%$ from its October 2007 peak. \\
\hline March 6, 2009 & The Bank of England announces up to $150 \mathrm{bn}$ pounds of quantitative easing. \\
\hline March 9, 2009 & $\begin{array}{l}\text { DJIA falls to } 6440 \text {, a percentage decline exceeding the one experienced during the } \\
\text { Great Depression. }\end{array}$ \\
\hline June 22, 2009 & $\begin{array}{l}\text { The World Bank announces that the global production for } 2009 \text { would fall by } 2.9 \% \text {, the } \\
\text { first decline since the second world war. }\end{array}$ \\
\hline April 21, 2010 & $\begin{array}{l}\text { The Greek government requests an initial loan of } € 45 \text { bn from the European Union (EU) } \\
\text { and International Monetary Fund (IMF). A few days later Standard \& Poor's cuts } \\
\text { Greece's sovereign debt rating to BB }+ \text {. Stock markets worldwide and the euro currency } \\
\text { decline in response to the downgrade. The Eurozone crisis worsens. }\end{array}$ \\
\hline
\end{tabular}




\section{Table B.1 (continued) \\ Calendar of key events of the crises}

\begin{tabular}{|c|c|}
\hline Date & ts \\
\hline May 2, 2010 & $\begin{array}{l}\text { The first Greek bailout ( } € 110 \mathrm{bn}) \text { by the ECB, the European Commission (EC) and the } \\
\text { IMF is approved. Credit rating agencies downgrade Greek government bonds even } \\
\text { lower. }\end{array}$ \\
\hline May 3, 2010 & $\begin{array}{l}\text { ECB announces it will accept all outstanding and new debt instruments issued or } \\
\text { guaranteed by the Greek government as collateral, in order to maintain banks' liquidity. }\end{array}$ \\
\hline May 8,2010 & The IMF Board approved a $€ 30 \mathrm{bn}$ Stand-by arrangement for Greece. \\
\hline July 21,2011 & $\begin{array}{l}\text { EU emergency measures continue a second rescue package is approved. Eurozone } \\
\text { leaders extend Greek, Irish and Portuguese loan repayment periods. They also approves } \\
\text { a new } € 109 \mathrm{bn} \text { support package for the newly created European Financial Stability } \\
\text { Facility (EFSF). }\end{array}$ \\
\hline August 11, 2011 & $\begin{array}{l}\text { European supervisors in Belgium, France, Italy and Spain announced a ban on } \\
\text { establishing or increasing short positions in financial institutions' stocks. }\end{array}$ \\
\hline September 1, 2011 & Spanish government bonds fall after nation sells debt. \\
\hline October 27, 2011 & $\begin{array}{l}\text { The Troika, a tripartite committee formed by the EC, the ECB and the IMF, offers } \\
\text { Greece a second bailout loan worth } € 172.6 \mathrm{bn} \text {, conditional on the implementation of } \\
\text { further austerity measures and a debt restructure agreement. }\end{array}$ \\
\hline October 31, 2011 & $\begin{array}{l}\text { The Greek Prime Minister announced a referendum to be held on } 4 \text { December, } 2011 \text { to } \\
\text { decide whether or not Greece was to accept the bailout conditions of the Troika. }\end{array}$ \\
\hline November 1, 2011 & Fitch \\
\hline November 3, 2011 & $\begin{array}{l}\text { er decided to cancel the referendum, and a new government } \\
\text { the following days. }\end{array}$ \\
\hline November 11, 2011 & premium surged to record high levels. \\
\hline November 24,2 & \\
\hline November 25,2 & kss' Issuer Default \\
\hline December 12, 2011 & $\begin{array}{l}\text { Moody's says Euro Area sovereigns remain under pressure in absence of decisive } \\
\text { initiatives. }\end{array}$ \\
\hline January 9, 2012 & $\begin{array}{l}\text { Belgian authorities publically announced the approved measures to correct the } \\
\text { excessive government deficit. }\end{array}$ \\
\hline February 12,2012 & k parliament approves the new austerity package. \\
\hline February 21,2012 & $\begin{array}{l}\text { The Troika agrees to provide a second bailout package } € 172.6 \mathrm{bn} \text { ( } € 28 \mathrm{bn} \text { from IMF and } \\
€ 144.6 \mathrm{bn} \text { from EFSF). }\end{array}$ \\
\hline March 2012 & $\begin{array}{l}\text { The Greek government defaults on its debt, the largest government default in history. } \\
\text { This counted as a "credit event" and holders of credit default swaps were paid } \\
\text { accordingly. }\end{array}$ \\
\hline May 15,2012 & $\begin{array}{l}\text { Speculations of a Greek exit from the Eurozone increase. This phase becomes known as } \\
\text { "Grexit" and influences market behaviour. }\end{array}$ \\
\hline June 9, 2012 & $\begin{array}{l}\text { Spain's } 10 \text {-year bonds reaches } 7 \% \text { and the country face difficulties in accessing bond } \\
\text { markets. The Eurozone crisis worsens. }\end{array}$ \\
\hline June 25,2012 & $\begin{array}{l}\text { The Cypriot Government requests a bailout from the EFSF/ESM (European Stability } \\
\text { Mechanism), citing difficulties in supporting its banking sector. }\end{array}$ \\
\hline September 2012 & $\begin{array}{l}\text { The ECB removes some of the pressure on Spain by announcing an "unlimited bond- } \\
\text { buying plan", conditional upon Spain signing a new sovereign bailout package with } \\
\text { EFSF/ESM. }\end{array}$ \\
\hline November 28, 2012 & $\begin{array}{l}\text { Spain's } € 100 \mathrm{bn} \text { support package earmarked for recapitalisation of the financial sector. } \\
\text { The first ESM recapitalisation tranche of } € 39.47 \mathrm{bn} \text { approved and transferred to the bank } \\
\text { recapitalisation fund (FROB) on } 11 \text { December } 2012 \text {. A second tranche of } € 1.86 \mathrm{n} \text { was } \\
\text { approved by the EC on } 20 \text { December with the aim to recapitalise "category } 2 \text { " banks } \\
\text { and transferred by ESM on } 5 \text { February } 2013 \text {. }\end{array}$ \\
\hline March 19, 2013 & $\begin{array}{l}\text { The final } € 10 \mathrm{bn} \text { support package for Cyprus financed partly by IMF ( } € 1 \mathrm{bn}) \text { and ESM } \\
\text { ( } € 9 \mathrm{bn} \text { ), featuring the direct closure of Laiki Bank and a forced bail-in recapitalisation } \\
\text { plan for Bank of Cyprus. }\end{array}$ \\
\hline
\end{tabular}




\section{Table 1}

\section{European and US Banks}

This table identifies the banks in our sample. Banks are assigned to countries based on the Datastream classification. Obs. refers to the available number of observations (CDS spread) for each bank in the sample. Total assets (December 2012 data) are expressed in thousand euros. For non-euro countries the Datastream average exchange rate in December 2012 is used.

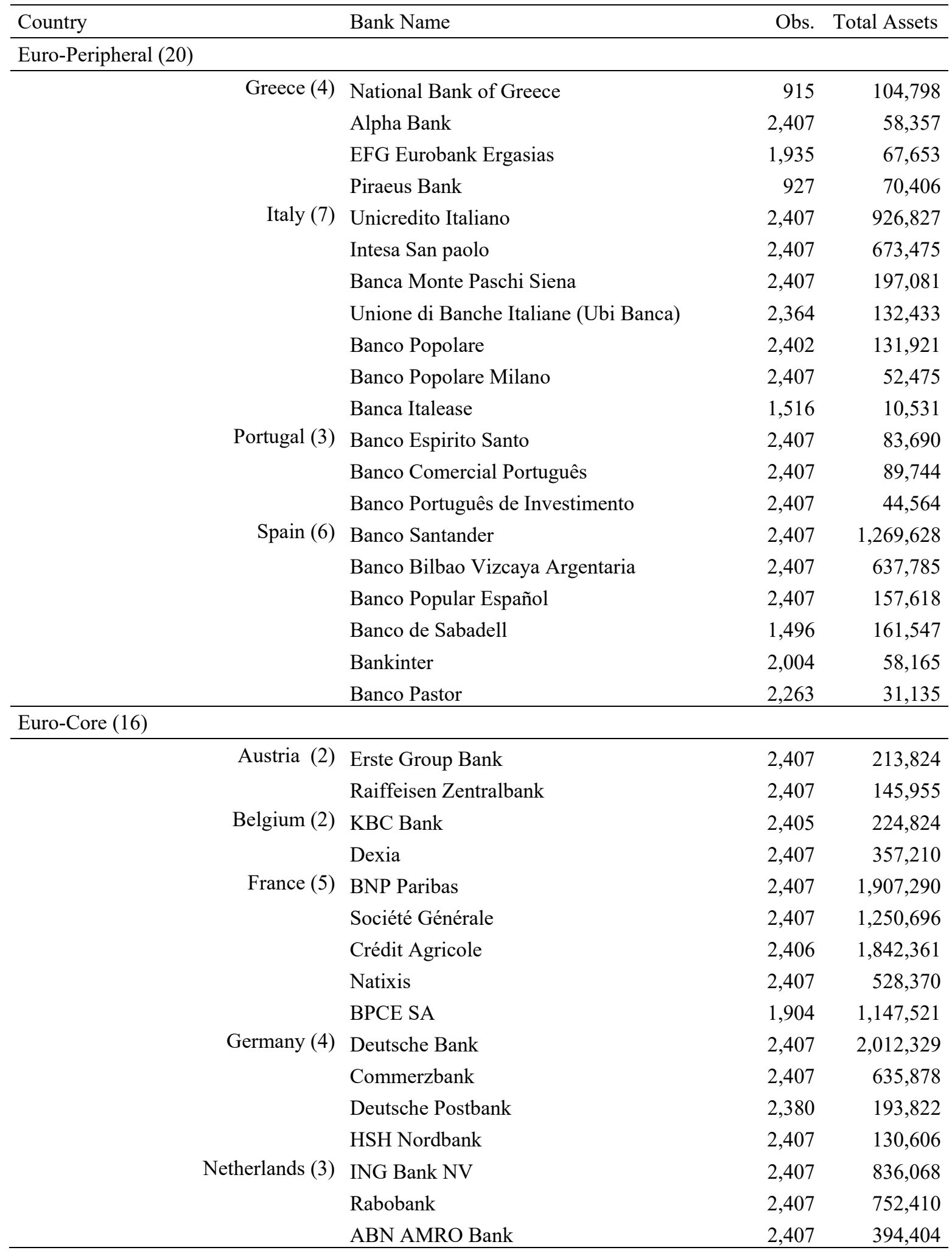


Table 1 (continued)

European and US Banks

\begin{tabular}{|c|c|c|c|}
\hline Country & Bank Name & Obs. & Total Assets \\
\hline \multicolumn{4}{|l|}{ Non-Euro (14) } \\
\hline Denmark (1) & Danske Bank & 2,394 & 466,708 \\
\hline Norway (1) & DNB NOR ASA & 1,274 & 273,743 \\
\hline \multirow[t]{4}{*}{ Sweden (4) } & Nordea Bank & 2,407 & 677,309 \\
\hline & Svenska Handelsbanken & 2,407 & 276,972 \\
\hline & Skandinaviska Enskilda Banken & 2,407 & 285,047 \\
\hline & Swedbank & 2,294 & 214,572 \\
\hline \multirow{8}{*}{$\begin{array}{r}\text { Switzerland (1) } \\
\text { UK (7) }\end{array}$} & Credit Suisse Group & 2,407 & 752,006 \\
\hline & HSBC Holdings PLC & 2,407 & $3,318,590$ \\
\hline & Lloyds Banking Group & 2,407 & $1,139,523$ \\
\hline & Standard Chartered & 2,050 & 784,517 \\
\hline & Alliance and Leicester PLC & 2,090 & 92,739 \\
\hline & Barclays & 2,407 & $1,837,366$ \\
\hline & Royal Bank of Scotland Group & 2,407 & $1,617,422$ \\
\hline & HBOS & 2,407 & 717,455 \\
\hline \multirow[t]{5}{*}{ US (5) } & Bank of America corporation & 2,407 & $1,673,231$ \\
\hline & JP Morgan Chase \& Co. & 2,407 & $1,786,754$ \\
\hline & US Bancorp & 1,314 & 268,001 \\
\hline & Wells Fargo \& Co. & 2,406 & $1,077,720$ \\
\hline & Citigroup Inc. & 2,407 & $1,412,247$ \\
\hline
\end{tabular}


Table 2

Bank CDS returns pair-wise correlations

This table illustrates the pair-wise correlations of bank CDS returns for all the countries in our sample. The banks in the sample are allocated in equally weighted portfolios, using average CDS data for the banks included in each country. Results are shown for the whole sample period (January 2004 to March 2013).

\begin{tabular}{|c|c|c|c|c|c|c|c|c|c|c|c|c|c|c|}
\hline & Austria & Belgium & Denmark & France & Germany & Greece & Italy & Netherlands & Norway & Portugal & Spain & Sweden & Switzerland & UK \\
\hline Austria & 1,0000 & & & & & & & & & & & & & \\
\hline Belgium & 0,2497 & 1,0000 & & & & & & & & & & & & \\
\hline Denmark & 0,2150 & 0,3027 & 1,0000 & & & & & & & & & & & \\
\hline Germany & 0,3304 & 0,4939 & 0,3331 & 0,6274 & 1,0000 & & & & & & & & & \\
\hline Greece & 0,0793 & 0,0788 & 0,0686 & 0,1084 & 0,0905 & 1,0000 & & & & & & & & \\
\hline Italy & 0,2871 & 0,4788 & 0,3530 & 0,6368 & 0,6487 & 0,1418 & 1,0000 & & & & & & & \\
\hline Portugal & 0,2226 & 0,3830 & 0,2160 & 0,4761 & 0,4989 & 0,1556 & 0,5631 & 0,5237 & 0,2410 & 1,0000 & & & & \\
\hline Spain & 0,2901 & 0,4516 & 0,3254 & 0,5487 & 0,5593 & 0,1753 & 0,6485 & 0,6133 & 0,3332 & 0,6272 & 1,0000 & & & \\
\hline Sweden & 0,2602 & 0,3259 & 0,4267 & 0,3944 & 0,4025 & 0,0873 & 0,4197 & 0,4271 & 0,6186 & 0,3002 & 0,4086 & 1,0000 & & \\
\hline Switzerland & 0,2596 & 0,5016 & 0,2754 & 0,6408 & 0,6981 & 0,0962 & 0,6449 & 0,7837 & 0,3605 & 0,4909 & 0,5343 & 0,3723 & 1,0000 & \\
\hline UK & 0,3370 & 0,5101 & 0,3309 & 0,6696 & 0,7329 & 0,0836 & 0,6788 & 0,8181 & 0,4279 & 0,5258 & 0,5949 & 0,4393 & 0,7867 & 1,0000 \\
\hline
\end{tabular}


Table 3

Descriptive statistics of European and US bank CDS spread and return series

This table illustrates the descriptive statistics (minimum, maximum, mean and standard deviation) for the daily 5-year CDS spreads (Panel A) and returns (Panel B). The banks in the sample are allocated in equally weighted portfolios, by geographic area, using average CDS data for the banks in the countries included in each geographical area. CDS spreads are reported in basis points and CDS returns in percentage form. Results are shown for the whole sample period (January 2004 to March 2013), and for three sub-periods: January 2004 to June 2007 (Pre-Crisis), July 2007 to September 2009 (Global Financial Crisis) and October 2009 to March 2013 (European Sovereign Debt Crisis). The lack of statistics for Norway in the first sub-period is due to the lack of data for the Norwegian bank until May 2008. Note that the indication of the reference period as "pre-crisis"; "global financial crisis" and "eurozone crisis" is only an approximation for ease of discussion. We do not impose specific time periods, as the estimations are carried out on a 200-day rolling window.

\section{Panel A}

\section{CDS spreads}

\begin{tabular}{|c|c|c|c|c|c|c|c|c|c|c|c|c|c|c|c|c|}
\hline & \multicolumn{4}{|c|}{ Jan2004-Mar2013 } & \multicolumn{4}{|c|}{$\begin{array}{c}\text { Pre-Crisis } \\
\text { Jan2004-Jun2007 }\end{array}$} & \multicolumn{4}{|c|}{$\begin{array}{c}\text { Financial Global Crisis } \\
\text { Jul2007-Sep2009 }\end{array}$} & \multicolumn{4}{|c|}{$\begin{array}{c}\text { European Sovereign Debt Crisis } \\
\text { Oct2009-Mar2013 }\end{array}$} \\
\hline & Min & Max & Mean & Std & Min & Max & Mean & Std & Min & Max & Mean & Std & Min & $\operatorname{Max}$ & Mean & Std \\
\hline Euro-Peripheral & 12.91 & $1,625.26$ & 277.91 & 358.01 & 12.91 & 31.02 & 19.46 & 4.15 & 19.58 & 216.25 & 100.70 & 50.29 & 113.47 & $1,625.26$ & 652.67 & 332.44 \\
\hline Greece & 15.00 & $4,190.93$ & 491.38 & 726.29 & 15.00 & 41.00 & 25.66 & 5.52 & 21.59 & 172.55 & 34.61 & 34.49 & 147.00 & $4,190.93$ & $1,255.79$ & 679.28 \\
\hline Italy & 9.07 & 694.93 & 157.47 & 164.88 & 9.07 & 36.87 & 20.60 & 6.42 & 21.83 & 379.23 & 144.21 & 80.34 & 67.72 & 694.93 & 303.69 & 166.10 \\
\hline Portugal & 10.50 & $1,483.58$ & 273.57 & 371.12 & 10.50 & 31.39 & 16.75 & 4.49 & 17.63 & 171.09 & 86.56 & 35.62 & 79.30 & $1,483.58$ & 653.04 & 362.88 \\
\hline Spain & 10.38 & 769.58 & 189.22 & 205.70 & 10.38 & 23.19 & 14.81 & 2.95 & 17.08 & 309.62 & 137.43 & 92.55 & 121.75 & 769.58 & 398.16 & 175.33 \\
\hline Euro-Core & 10.13 & 384.93 & 110.31 & 97.36 & 10.13 & 35.10 & 15.68 & 3.78 & 24.37 & 274.42 & 119.84 & 61.30 & 98.31 & 384.93 & 199.27 & 75.69 \\
\hline Austria & 3.83 & 510.25 & 123.24 & 97.85 & 3.83 & 117.83 & 26.05 & 17.03 & 74.15 & 510.25 & 170.10 & 100.35 & 123.05 & 364.59 & 190.60 & 55.97 \\
\hline Belgium & 5.50 & 709.49 & 175.81 & 185.52 & 5.50 & 13.40 & 9.75 & 1.48 & 10.60 & 395.70 & 172.89 & 100.86 & 136.14 & 709.49 & 344.68 & 168.79 \\
\hline France & 5.18 & 356.17 & 89.69 & 83.65 & 5.18 & 58.23 & 14.96 & 8.39 & 9.92 & 156.01 & 78.85 & 35.29 & 60.32 & 356.17 & 171.87 & 72.42 \\
\hline Germany & 10.22 & 276.11 & 87.01 & 66.20 & 10.22 & 37.10 & 19.09 & 5.35 & 16.25 & 182.29 & 99.02 & 44.56 & 88.95 & 276.11 & 147.53 & 43.83 \\
\hline Netherlands & 3.83 & 254.40 & 75.77 & 67.83 & 3.83 & 14.53 & 8.54 & 2.88 & 6.83 & 172.73 & 78.35 & 38.16 & 64.07 & 254.40 & 141.68 & 48.63 \\
\hline Non-Euro & 7.50 & 245.60 & 75.42 & 64.06 & 7.50 & 18.70 & 12.80 & 2.89 & 11.19 & 227.82 & 91.65 & 51.99 & 63.79 & 245.60 & 127.86 & 47.59 \\
\hline Denmark & 1.00 & 344.80 & 83.59 & 89.72 & 1.00 & 21.00 & 8.80 & 4.16 & 4.10 & 225.00 & 81.76 & 61.97 & 60.56 & 344.80 & 158.91 & 86.72 \\
\hline Norway & 37.50 & 212.00 & 100.46 & 39.37 & - & - & - & - & 37.50 & 188.11 & 103.21 & 41.18 & 49.54 & 212.00 & 99.35 & 38.55 \\
\hline Sweden & 9.63 & 242.38 & 68.69 & 57.92 & 9.63 & 25.43 & 15.93 & 4.02 & 13.17 & 242.38 & 88.46 & 65.27 & 67.00 & 216.96 & 108.92 & 38.15 \\
\hline Switzerland & 9.20 & 262.88 & 74.68 & 57.55 & 9.20 & 25.50 & 16.25 & 4.17 & 17.50 & 262.88 & 99.82 & 51.36 & 52.80 & 213.45 & 117.14 & 37.65 \\
\hline UK & 4.37 & 285.29 & 88.50 & 74.20 & 4.37 & 20.40 & 10.11 & 3.01 & 9.97 & 230.15 & 107.52 & 50.30 & 77.90 & 285.29 & 154.98 & 46.14 \\
\hline US & 8.13 & 337.73 & 86.39 & 68.21 & 8.13 & 30.93 & 17.67 & 6.01 & 14.53 & 337.73 & 123.78 & 71.26 & 74.15 & 262.02 & 131.25 & 36.76 \\
\hline
\end{tabular}


Table 3 (continued)

Descriptive statistics of European and US bank CDS spread and return series

Panel B

\begin{tabular}{|c|c|c|c|c|c|c|c|c|c|c|c|c|c|c|c|c|}
\hline \multicolumn{17}{|c|}{ CDS returns } \\
\hline & \multicolumn{4}{|c|}{ Jan2004-Mar2013 } & \multicolumn{4}{|c|}{$\begin{array}{c}\text { Pre-Crisis } \\
\text { Jan2004-Jun2007 } \\
\end{array}$} & \multicolumn{4}{|c|}{$\begin{array}{c}\text { Financial Global Crisis } \\
\text { Jul2007-Sep2009 } \\
\end{array}$} & \multicolumn{4}{|c|}{$\begin{array}{c}\text { European Sovereign Debt Crisis } \\
\text { Oct2009-Mar2013 }\end{array}$} \\
\hline & Min & Max & Mean & Std & Min & Max & Mean & Std & Min & Max & Mean & Std & Min & Max & Mean & Std \\
\hline Euro-Peripheral & -529.32 & $1,113.66$ & -0.38 & 45.77 & -20.17 & 24.82 & 0.04 & 2.64 & -119.99 & 49.87 & -0.56 & 15.17 & -529.32 & $1,113.66$ & -0.69 & 73.48 \\
\hline Greece & $-1,679.64$ & $4,246.79$ & 0.12 & 141.40 & -46.03 & 66.70 & 0.06 & 6.21 & -429.05 & 38.91 & -0.75 & 21.06 & $-1,679.64$ & $4,246.79$ & 0.75 & 229.58 \\
\hline Italy & -207.26 & 290.88 & -0.58 & 29.73 & -28.04 & 18.66 & 0.06 & 3.49 & -145.56 & 168.71 & -0.23 & 26.75 & -207.26 & 290.88 & -1.46 & 43.20 \\
\hline Portugal & -312.20 & 527.90 & -0.52 & 47.21 & -26.66 & 26.85 & 0.03 & 5.48 & -143.22 & 97.19 & -0.56 & 19.29 & -312.20 & 527.90 & -1.05 & 75.10 \\
\hline Spain & -199.67 & 305.07 & -0.54 & 31.15 & -35.43 & 34.18 & 0.02 & 2.81 & -147.80 & 134.64 & -0.69 & 22.13 & -199.67 & 305.07 & -1.01 & 47.41 \\
\hline Euro-Core & -136.94 & 162.02 & -0.22 & 18.65 & -71.55 & 49.50 & 0.04 & 10.50 & -136.94 & 105.44 & -0.53 & 21.51 & -120.39 & 162.02 & -0.29 & 22.63 \\
\hline Austria & -345.24 & 289.12 & -0.14 & 37.83 & -345.24 & 224.47 & -0.07 & 46.10 & -246.66 & 289.12 & -0.31 & 39.66 & -150.47 & 210.10 & -0.11 & 25.34 \\
\hline Belgium & -366.81 & 246.17 & -0.40 & 30.44 & -11.74 & 11.46 & 0.00 & 2.20 & -366.81 & 246.17 & -0.95 & 40.42 & -220.90 & 204.95 & -0.44 & 37.33 \\
\hline France & -179.67 & 222.69 & -0.22 & 24.30 & -179.67 & 153.02 & 0.10 & 19.88 & -114.20 & 80.18 & -0.40 & 18.69 & -159.43 & 222.69 & -0.44 & 30.71 \\
\hline Germany & -168.58 & 116.51 & -0.12 & 17.11 & -77.69 & 94.34 & 0.12 & 9.37 & -111.95 & 107.78 & -0.59 & 19.11 & -168.58 & 116.51 & -0.05 & 21.24 \\
\hline Netherlands & -146.38 & 115.22 & -0.24 & 16.80 & -9.33 & 9.49 & 0.02 & 1.51 & -146.38 & 115.22 & -0.40 & 22.90 & -71.83 & 113.77 & -0.40 & 20.16 \\
\hline Non-Euro & -96.17 & 102.68 & -0.15 & 13.60 & -16.88 & 14.75 & 0.02 & 2.79 & -96.17 & 83.68 & -0.41 & 18.28 & -81.73 & 102.68 & -0.15 & 16.32 \\
\hline Denmark & -392.76 & 209.57 & -0.21 & 20.09 & -64.29 & 36.70 & 0.01 & 6.37 & -392.76 & 209.57 & -0.43 & 26.32 & -167.62 & 150.21 & -0.27 & 23.99 \\
\hline Norway & -202.99 & 157.05 & -0.10 & 19.70 & - & - & - & - & -202.99 & 157.05 & -0.01 & 26.08 & -126.47 & 112.43 & -0.13 & 16.44 \\
\hline Sweden & -188.22 & 100.05 & -0.12 & 12.54 & -24.14 & 21.53 & 0.04 & 3.43 & -188.22 & 69.78 & -0.46 & 18.09 & -73.63 & 100.05 & -0.06 & 13.90 \\
\hline Switzerland & -167.31 & 195.38 & -0.13 & 21.15 & -24.68 & 21.98 & -0.01 & 2.95 & -167.31 & 195.38 & -0.35 & 30.97 & -142.30 & 186.97 & -0.10 & 23.58 \\
\hline UK & -191.07 & 227.54 & -0.16 & 21.97 & -43.43 & 45.80 & 0.03 & 7.78 & -191.07 & 227.54 & -0.45 & 30.34 & -103.86 & 182.30 & -0.17 & 24.95 \\
\hline US & -178.96 & 230.81 & -0.13 & 24.60 & -19.23 & 14.69 & 0.02 & 2.45 & -178.96 & 230.81 & -0.85 & 40.16 & -168.85 & 118.20 & 0.20 & 23.53 \\
\hline
\end{tabular}


Table 4

\section{Robustness Tests}

The table reports the results of additional analyses, for systematic and idiosyncratic contagion. Panel A reports the key differences in results when using portfolios weighted by total assets. The original analysis was carried out using equally weighted portfolios. Panel B reports the results when excluding the portfolio of US banks from the analysis. The sample period is January 2004 to March 2013, but the indices start in October 2004, since a 200-day rolling window is used to obtain the evolution over time. Note that only remarkable differences in the values of the spillover indices (and relative dates) are displayed. TS is the total spillover index. NDS is the net directional spillover index and NPS is net pairwise spillover index. US is the portfolio of CDS returns of US banks. EP is the portfolio of CDS returns of euro-peripheral banks. EC is the portfolio of CDS returns of euro-core banks. NE is the portfolio of CDS returns of non- euro banks.

\begin{tabular}{|c|c|c|c|c|}
\hline \multicolumn{5}{|c|}{ Panel A: Equally Weighted portfolios vs. Weighted portfolios by total assets } \\
\hline & \multicolumn{2}{|c|}{ Systematic Contagion } & \multicolumn{2}{|c|}{ Idiosyncratic Contagion } \\
\hline & $\begin{array}{c}\text { Equally Weighted } \\
\text { portfolios }\end{array}$ & $\begin{array}{l}\text { Weighted } \\
\text { portfolios }\end{array}$ & $\begin{array}{c}\text { Equally Weighted } \\
\text { portfolios }\end{array}$ & $\begin{array}{l}\text { Weighted } \\
\text { portfolios }\end{array}$ \\
\hline Dates & \multicolumn{2}{|c|}{ 2006Q1-Q3 } & \multicolumn{2}{|c|}{ Aug 2007} \\
\hline TS index & $\begin{array}{c}47.70 \% \\
\text { on average }\end{array}$ & $\begin{array}{c}62.44 \% \\
\text { on average }\end{array}$ & $\begin{array}{c}\text { A peak of } \\
16.23 \%\end{array}$ & A peak of $37.46 \%$ \\
\hline $\begin{array}{c}\text { NDS } \\
\& \\
\text { NPS } \\
\text { indices }\end{array}$ & $\begin{array}{c}\text { US net receiver of } \\
\text { systematic contagion } \\
(26.88 \% \text { on average): } 2.60 \% \text {, } \\
11.32 \% \text { and } 12.96 \% \text {, from } \\
\text { EP, EC and NE, respectively }\end{array}$ & $\begin{array}{l}\text { US net receiver of systematic } \\
\text { contagion } \\
(43.38 \% \text { on average): } 15.26 \% \text {, } \\
13.17 \% \text { and } 14.95 \% \text {, from EP, } \\
\text { EC and NE, respectively }\end{array}$ & $\begin{array}{c}\text { EP receives } \\
\text { on average } \\
0.81 \% \text { and } 0.75 \% \text { from } \\
\text { US and NE, respectively }\end{array}$ & $\begin{array}{c}\text { EP receives } \\
\text { on average } 12.8 \% \text { and } \\
14.1 \% \text { from US and } \\
\text { NE, respectively }\end{array}$ \\
\hline
\end{tabular}

\section{Panel B: Without the US}

\begin{tabular}{c|c|c|c|c|c|c}
\hline & \multicolumn{2}{|c|}{ Systematic Contagion } & \multicolumn{3}{c}{ Idiosyncratic Contagion } \\
\hline Dates & Aug 07 & Jul 2007- Dec 07 & May 10 & Sep 11 & Oct 11 & $\begin{array}{c}\text { May 12 - Mar } \\
\mathbf{1 3}\end{array}$ \\
\hline \multirow{2}{*}{ TS index } & $\begin{array}{c}\text { A peak of } \\
74.58 \%\end{array}$ & $\begin{array}{c}61.23 \% \\
\text { on average }\end{array}$ & $\begin{array}{c}\text { A peak of } \\
35.01 \%\end{array}$ & $\begin{array}{c}\text { A peak of } \\
40.43 \%\end{array}$ & $\begin{array}{c}\text { A peak of } \\
44.36 \%\end{array}$ & $\begin{array}{c}21.26 \% \\
\text { on average }\end{array}$ \\
\hline TS index & $\begin{array}{c}\text { A peak of } \\
\text { Excluding US }\end{array}$ & $\begin{array}{c}47.40 \% \\
\text { on average }\end{array}$ & $\begin{array}{c}7.45 \% \\
\text { on average }\end{array}$ & $\begin{array}{c}\text { A peak of } \\
20.50 \%\end{array}$ & $\begin{array}{c}\text { A peak of } \\
24.45 \%\end{array}$ & $\begin{array}{c}11.98 \% \\
\text { on average }\end{array}$ \\
\hline
\end{tabular}




\section{Figure 1}

\section{Principal Component Analysis}

This figure reports the time evolution of the proportion of variance (in percentage) explained by the first four principal components of banks' CDS returns series. The sample period is January 2004 to March 2013, but the figure starts in October 2004 since a 200-day rolling window is used to obtain the evolution over time.

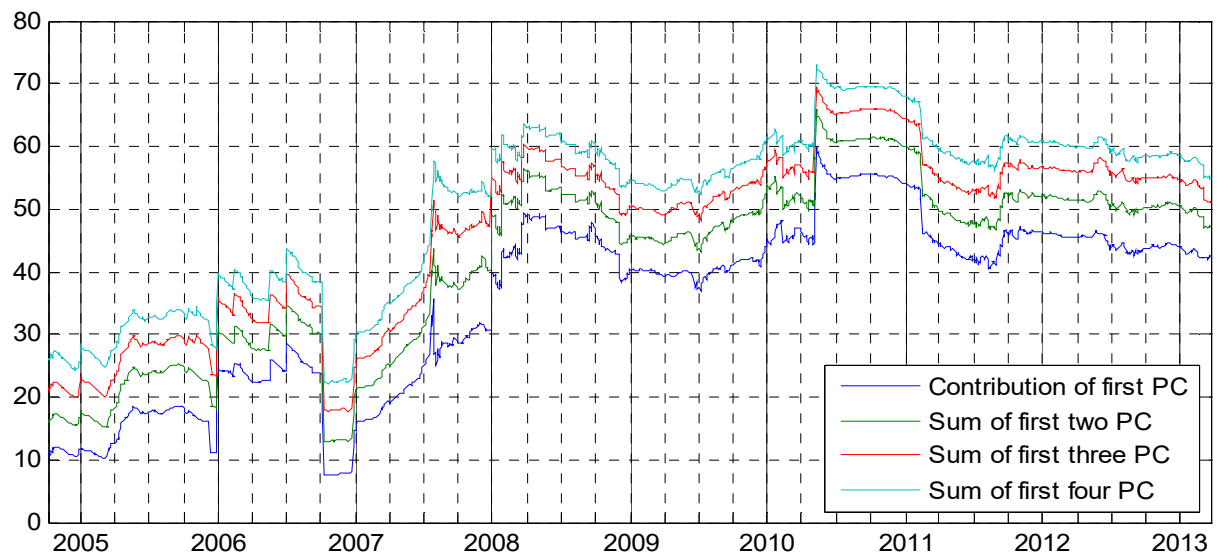


Figure 2

Time evolution of CDS spreads and returns series

Panel A: Daily time series of CDS spreads (in basis points); Panel B: Daily time series of CDS returns. Panel A and Panel B report the CDS spreads and returns for the four equally weighted portfolios, sorted by the geographical area where banks are headquartered. The sample period is January 2004 to March 2013. The scale in the euro-peripheral portfolio is from 0 to 1,800 (Panel A) and from -8 to 12 (Panel B); in all other portfolios the scale is from 0 to 400 (Panel A) and from -3 to 3 (Panel B).

\section{Panel A}
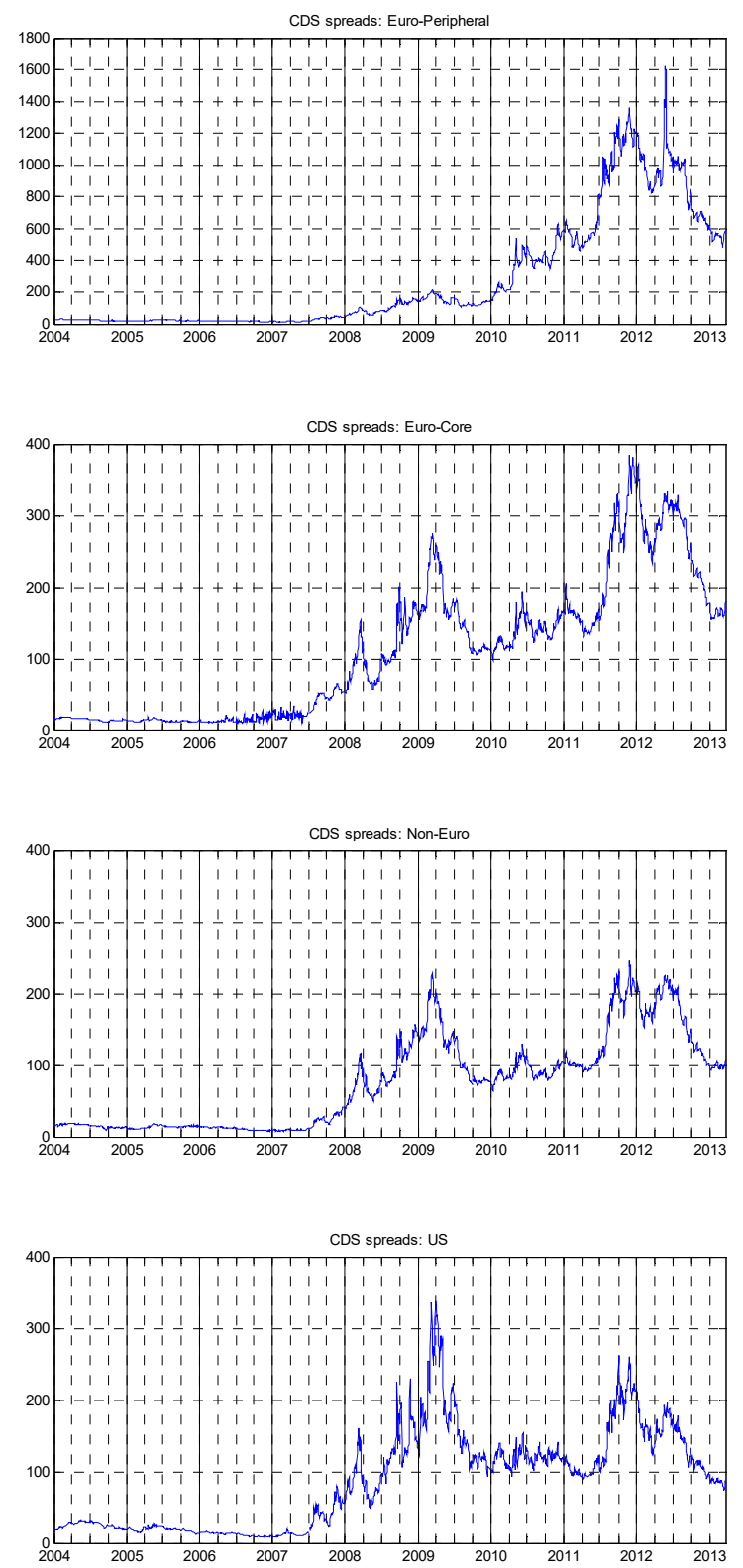

\section{Panel B}
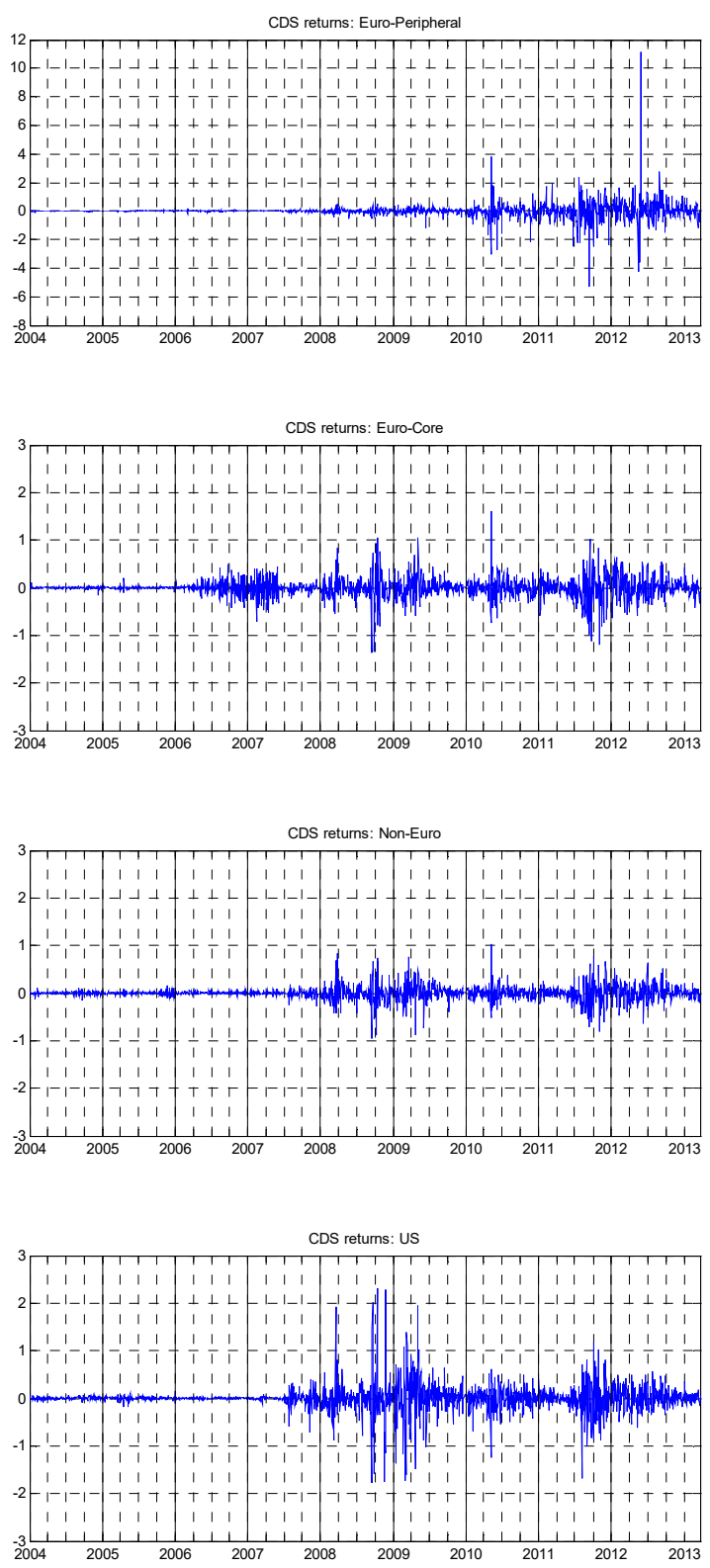
Figure 3

Total return spillover index

This figure reports the time evolution of the total return spillover index for systematic contagion (TSI-SC in black), computed using systematic CDS returns, and idiosyncratic contagion (TSI-IC in grey), computed using idiosyncratic CDS returns. It measures (on average) the percentage of the forecast error variance in all the series that comes from contagion due to shocks. Returns of the four equally weighted portfolios sorted by geographical area are used. The sample period is January 2004 to March 2013, but the index starts in October 2004, since a 200-day rolling window is used to obtain the evolution over time.
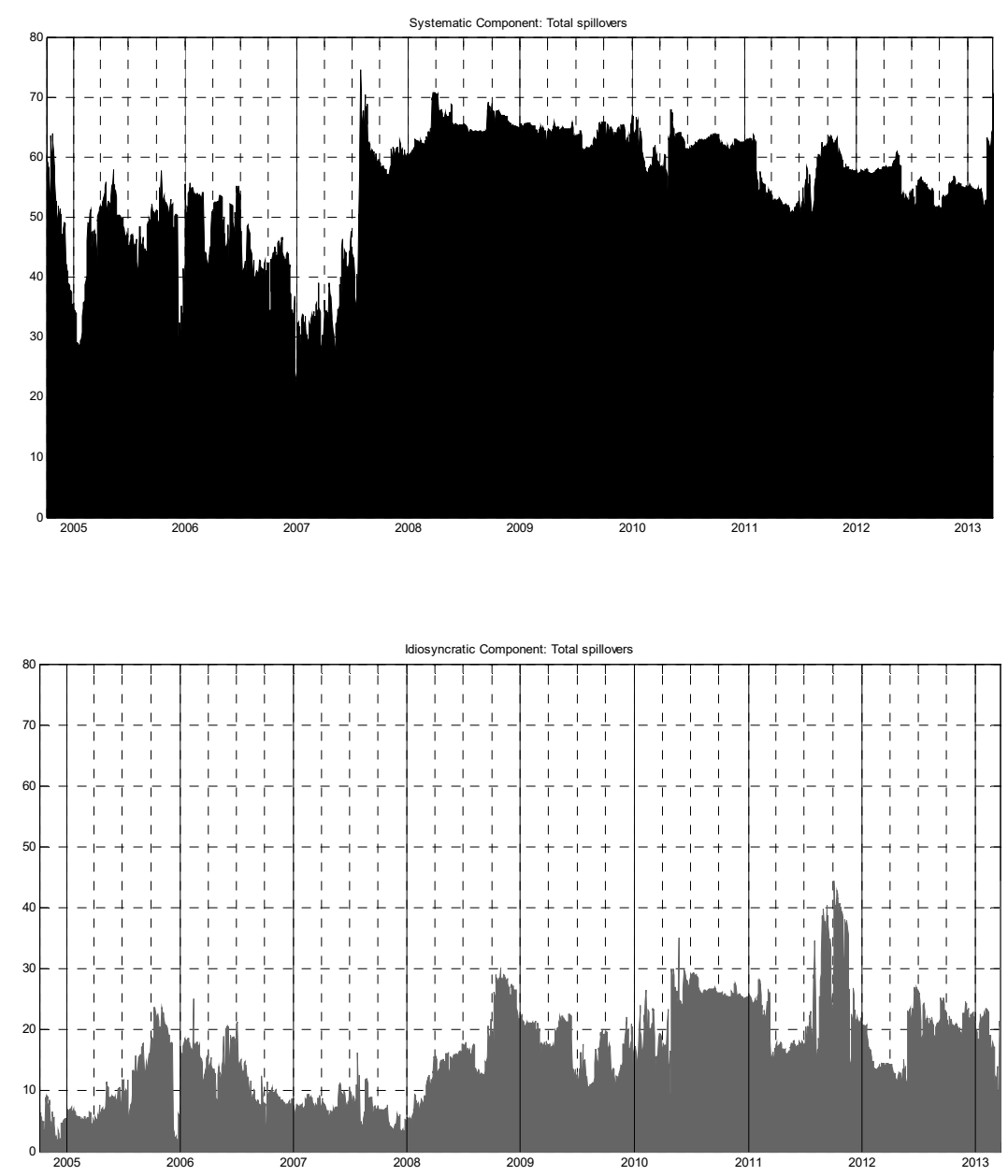


\section{Figure 4}

\section{Net directional return spillover indices}

This figure reports the time evolution of the net directional return spillover indices for systematic contagion (in black), computed using systematic CDS returns, and idiosyncratic contagion (in grey), computed using idiosyncratic returns. They measure the spillover due to shocks (in percentage terms) transmitted by each portfolio to all others. Positive (negative) values indicate that the corresponding portfolio is, in net terms, a transmitter (receiver) of return spillover effects to all others. Returns of the four equally weighted portfolios sorted by geographical area are used. Panel A illustrates the net directional spillovers from the euro-peripheral portfolio to all others. Panel B illustrates the net directional spillovers from the euro-core portfolio to all others. Panel $\mathrm{C}$ illustrates the net directional spillovers from the non-euro portfolio to all others. Finally, Panel D illustrates the net directional spillovers from the US portfolio to all others. The sample period is January 2004 to March 2013, but the indices start on October 2004 since a 200-days rolling window is used to get the evolution over time.

\section{Panel A}
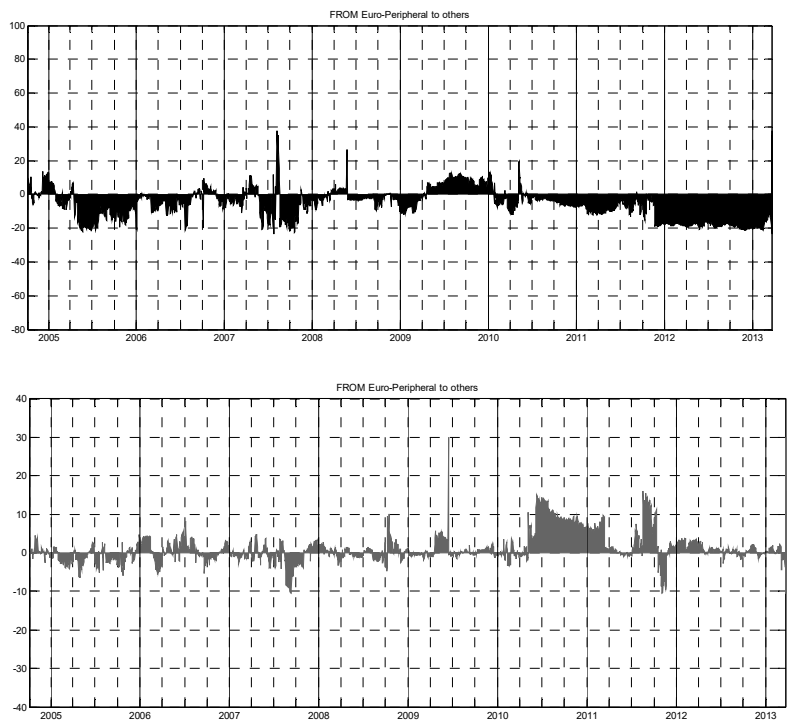

\section{Panel C}
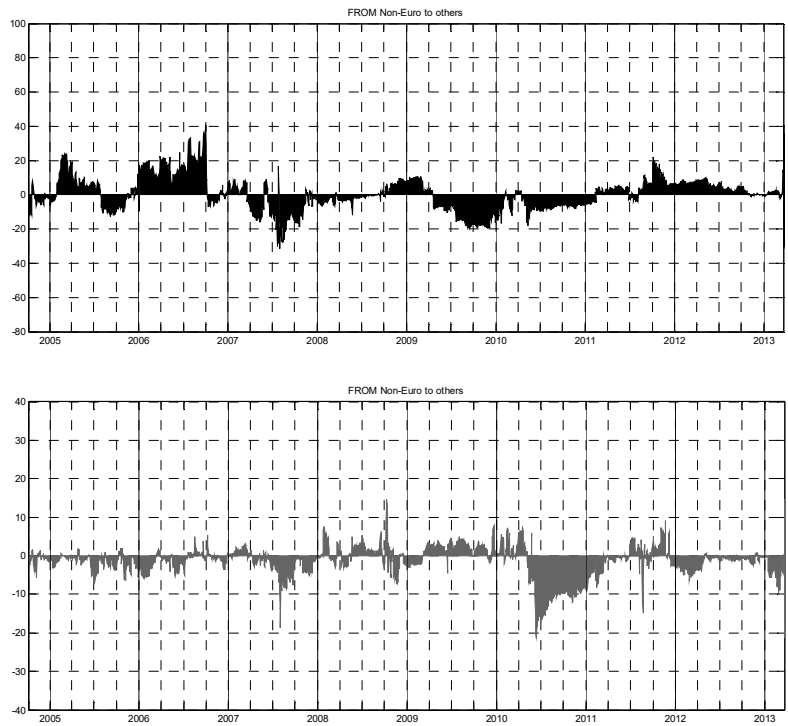

Panel B
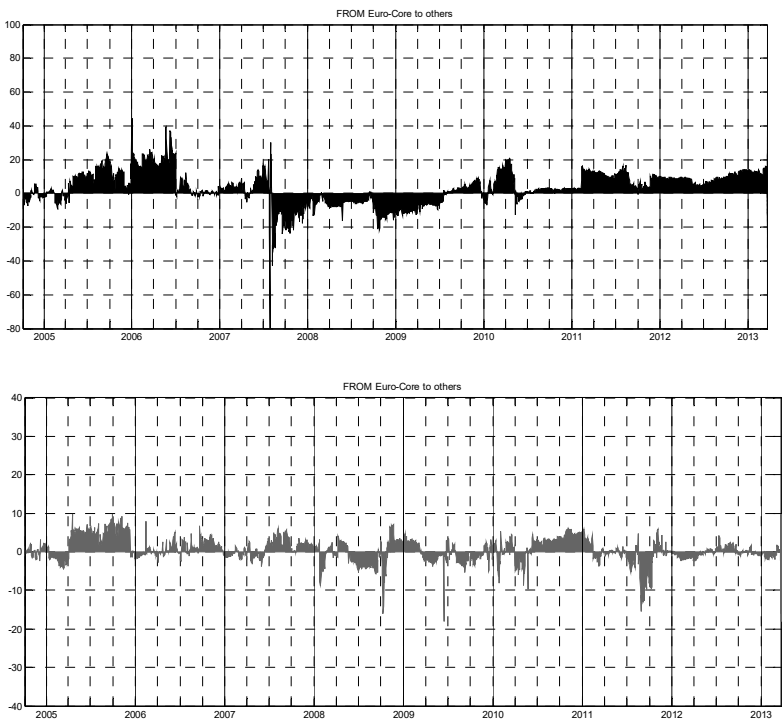

Panel D
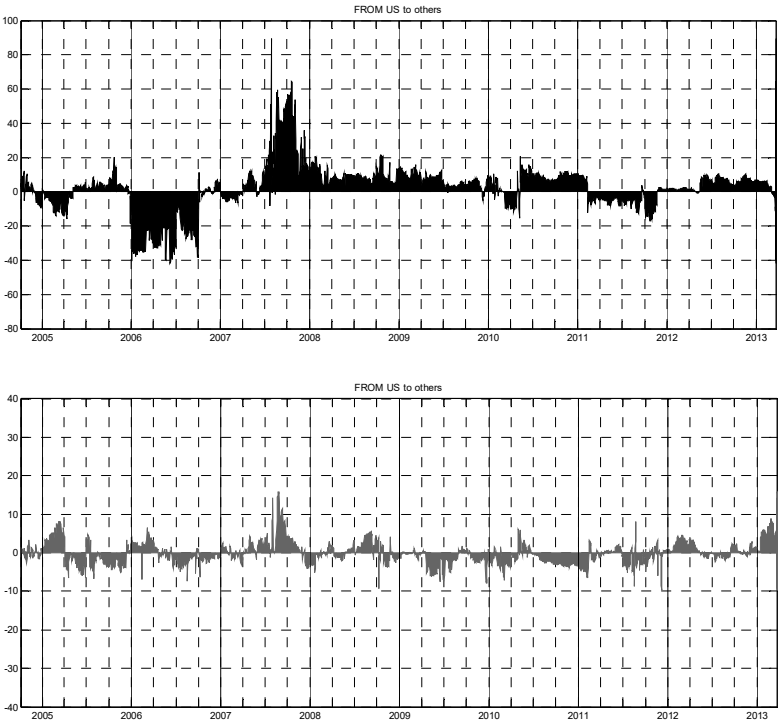


\section{Figure 5}

Net pairwise return spillover relationships

This figure reports the time evolution of the net pairwise return spillover indices for systematic contagion (in black), computed using systematic CDS returns, and idiosyncratic contagion (in grey), computed using idiosyncratic returns. They measure the net spillover due to shocks (in percentage terms) transmitted between each pair of portfolios. Returns of the four equally weighted portfolios, sorted by geographical area, are used. EP, EC, NE and US refers to euro-peripheral (Greece, Italy, Portugal and Spain); euro-core (Austria, Belgium, France Germany and Netherlands), non-euro (Denmark, Norway, Sweden, Switzerland and the UK) and US, respectively. The sample period is January 2004 to March 2013; the time evolution of pairwise relationships is also summarized in three sub-periods: the pre-crisis period (January 2004 - June 2007), the financial crisis period (July 2007 - September 2009) and the Eurozone sovereign debt crisis period (October 2009 - March 2013). Note that the division into the three sub-periods is an approximation for ease of discussion as the GVAR estimations are carried out on a 200day rolling window framework.

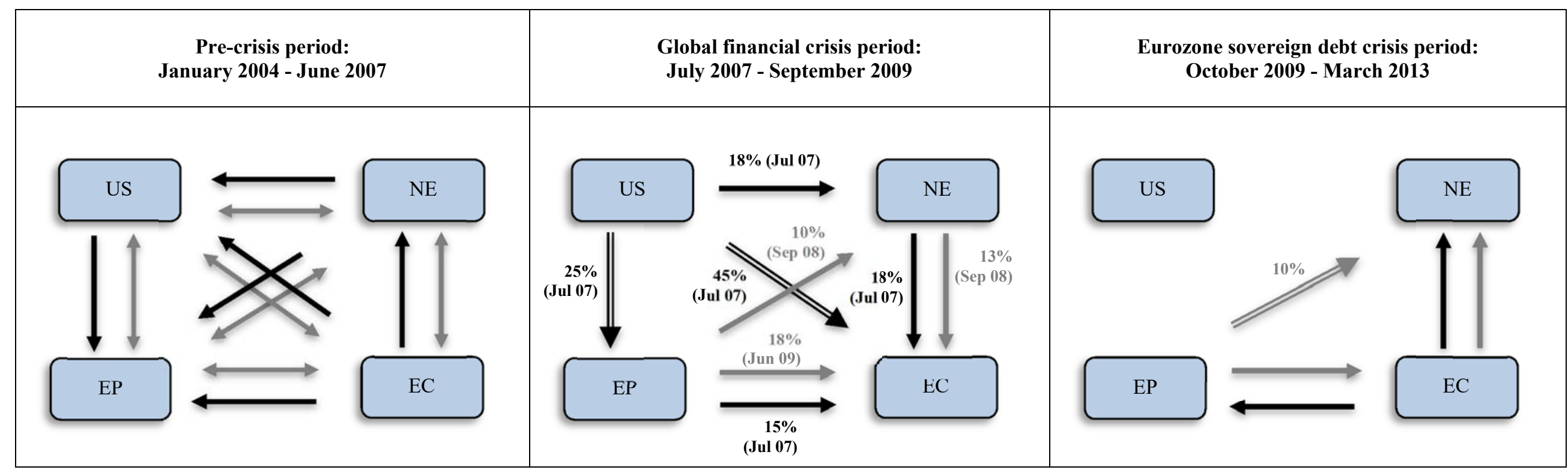




\section{Figure 6}

\section{Comparison with Market Indices}

The figure (Panel A, B, C, D and E) illustrates the time evolution of a sovereign CDS index that reflects the average of all sovereign CDS spreads in the sample at particular points in time over the sample period. Note that data on US sovereign CDS are available only from before December 2007. Prior to that, the Sovereign CDS Index includes only European countries. Panel F and $\mathrm{G}$ reflects the evolution over time of two stock returns portfolios for the Greek and Spanish banks in our sample to show the average stock returns (Greek Banks Stock Returns Index and Spanish Banks Stock Returns Index).

\section{Sovereign CDS index}

Panel A. April 2007- January 2008

Panel B. 2008
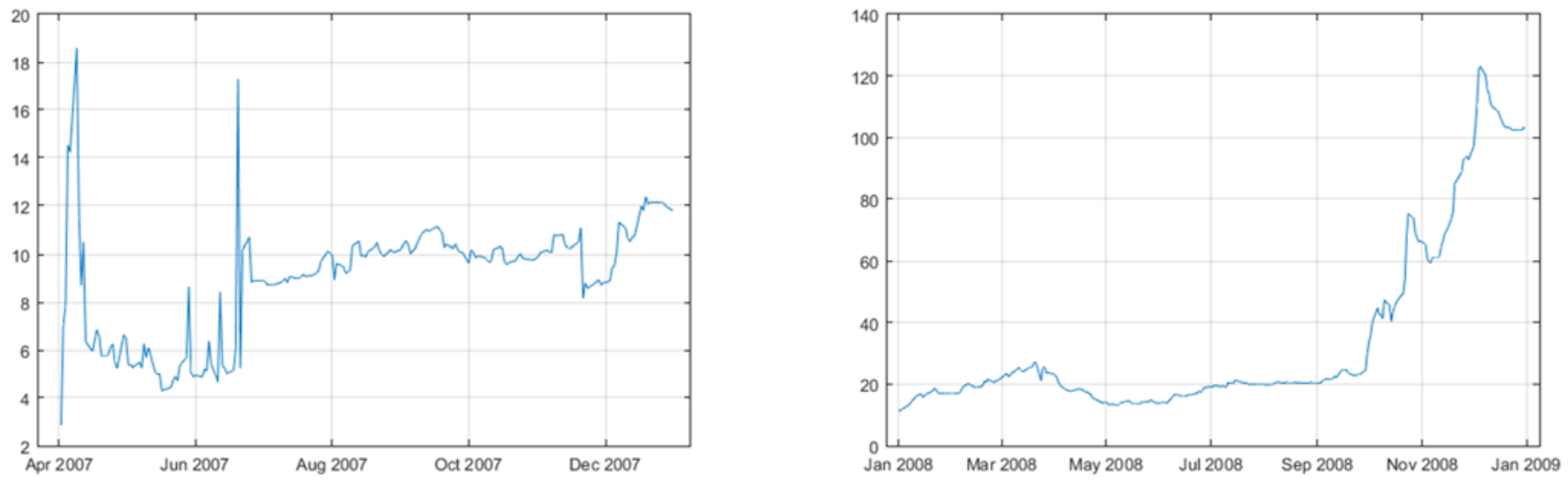

Panel C. 2010

Panel D. October 2009-March 2013
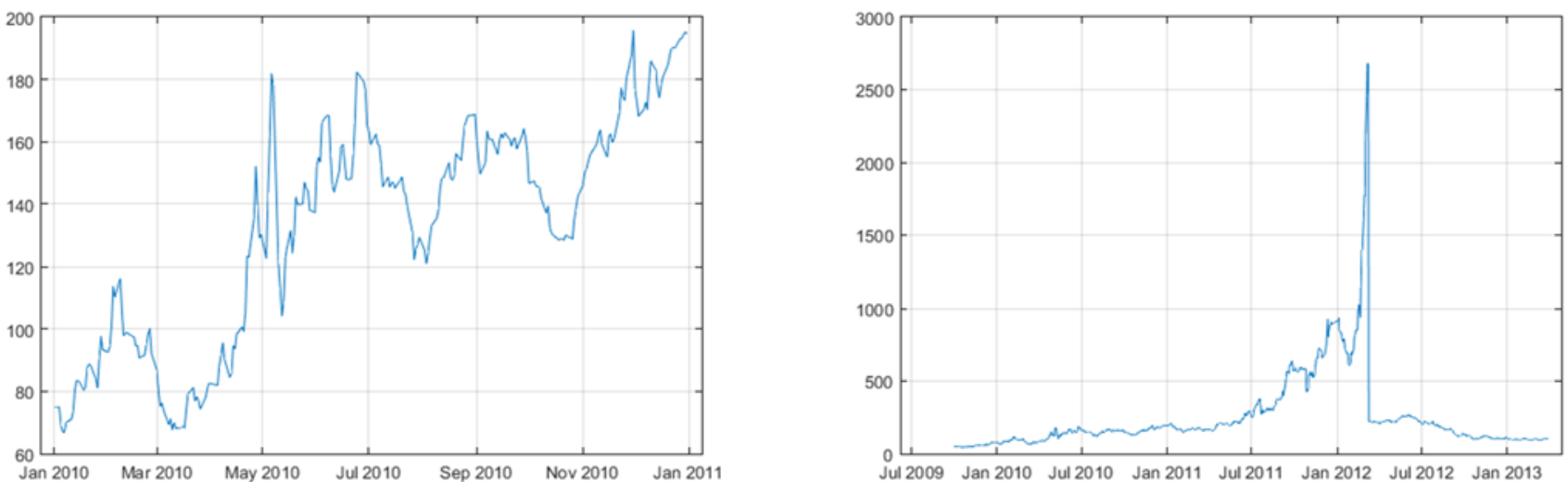

Panel E. September-December 2012

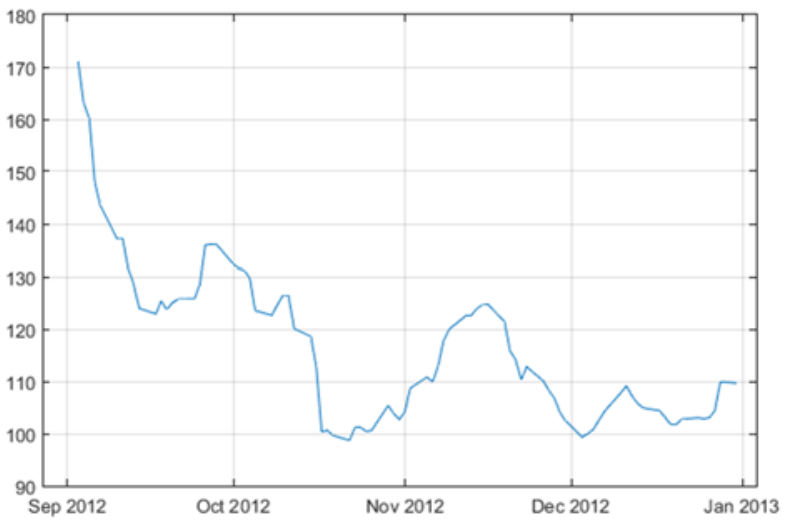


Figure 6 (continued)

Comparison with Market Indices

Bank Stock returns index

Panel F. Greek Banks (2010)

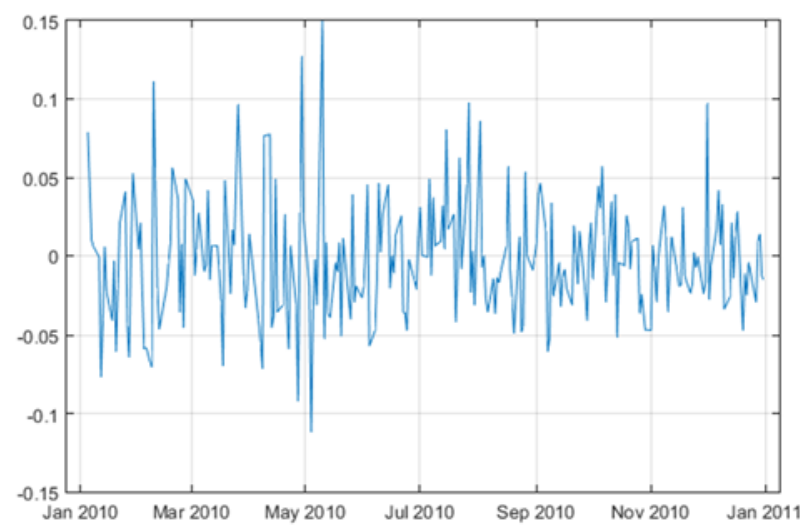

Panel G. Spanish Banks (September-December 2012)

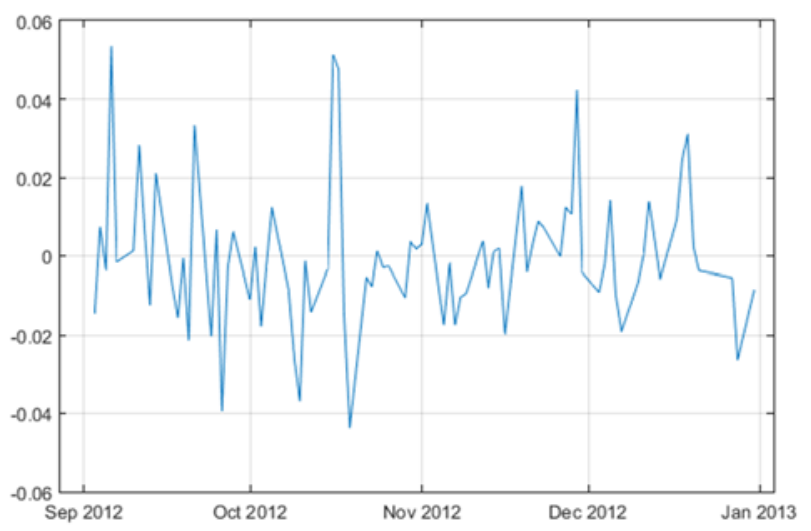




\section{Figure 7}

Total return spillover index (within euro-peripheral)

This figure reports the time evolution of the total return spillover index for systematic contagion (in black), computed using systematic CDS returns, and idiosyncratic contagion (in grey), computed using idiosyncratic CDS returns. It measures (on average) the percentage of the forecast error variance in all the series that comes from contagion due to shocks. CDS returns for equally weighted portfolio of banks in Greece, Italy, Portugal and Spain are used. The sample period is June 2009 to March 2013, but the index starts in March 2010, since a 200-day rolling window is used to obtain the evolution over time.
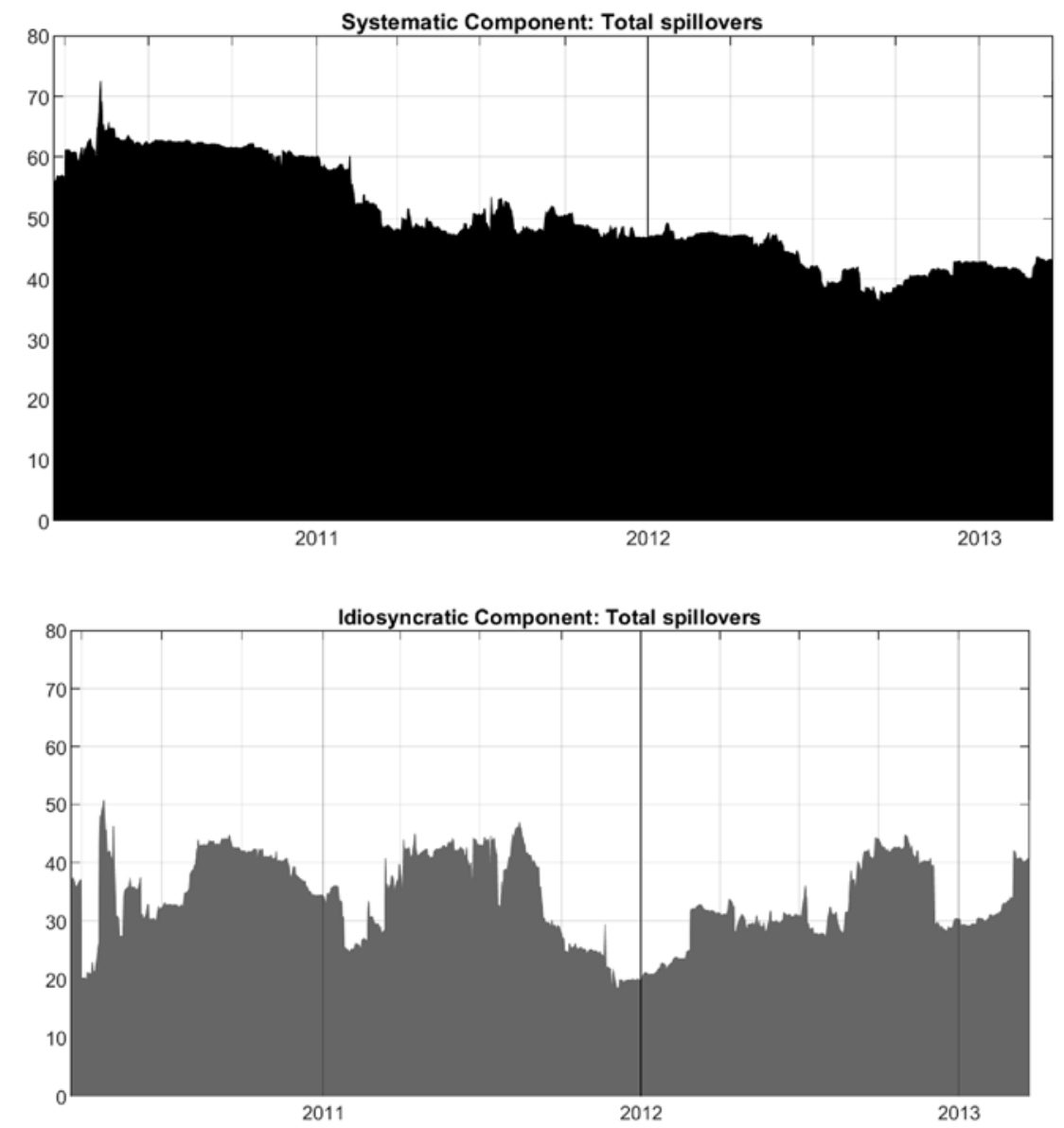


\section{Figure 8}

\section{Net directional return spillover indices (within euro-peripheral)}

This figure reports the time evolution of the net directional return spillover indices for systematic contagion (in black), computed using systematic CDS returns, and idiosyncratic contagion (in grey), computed using idiosyncratic returns. They measure the spillover due to shocks (in percentage terms) transmitted by each portfolio to all others. Positive (negative) values indicate that the corresponding portfolio is, in net terms, a transmitter (receiver) of return spillover effects to all others. CDS returns for equally weighted portfolio of banks in Greece, Italy, Portugal and Spain are used. Panel A illustrates the net directional spillovers from Greece to all others. Panel B illustrates the net directional spillovers from Italy to all others. Panel C illustrates the net directional spillovers from Portugal to all others. Finally, Panel D illustrates the net directional spillovers from Spain to all others. The sample period is June 2009 to March 2013, but the index starts in March 2010, since a 200-day rolling window is used to obtain the evolution over time.

\section{Panel A}
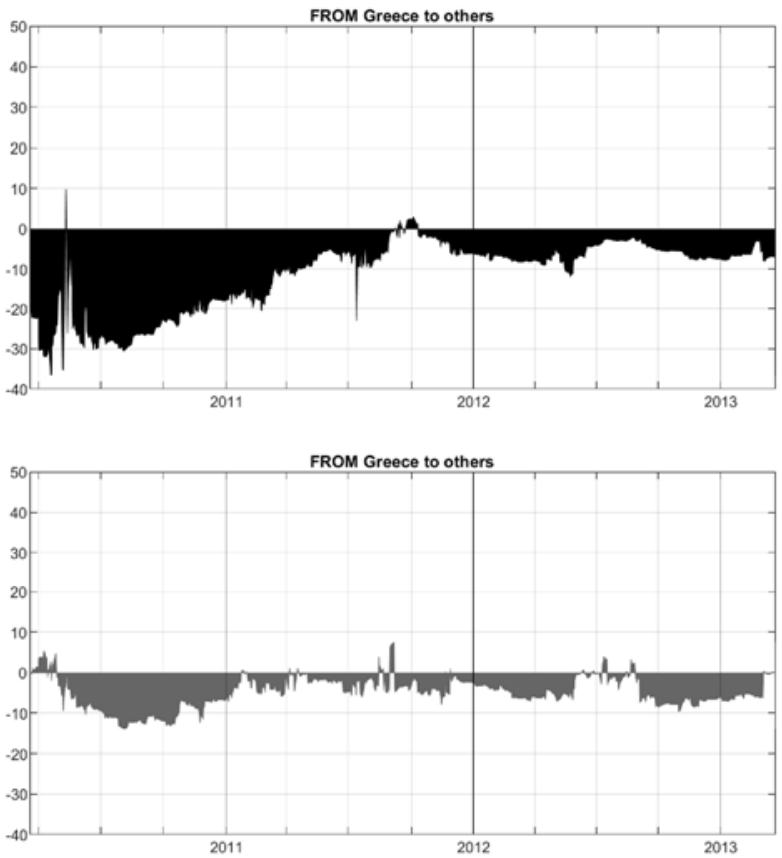

\section{Panel C}
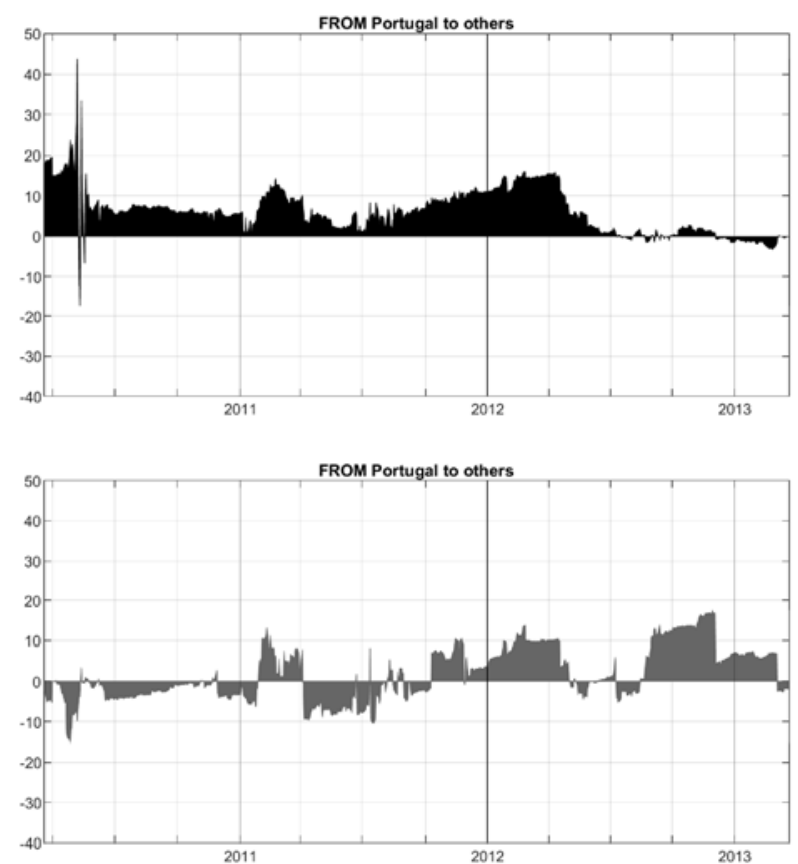

\section{Panel B}
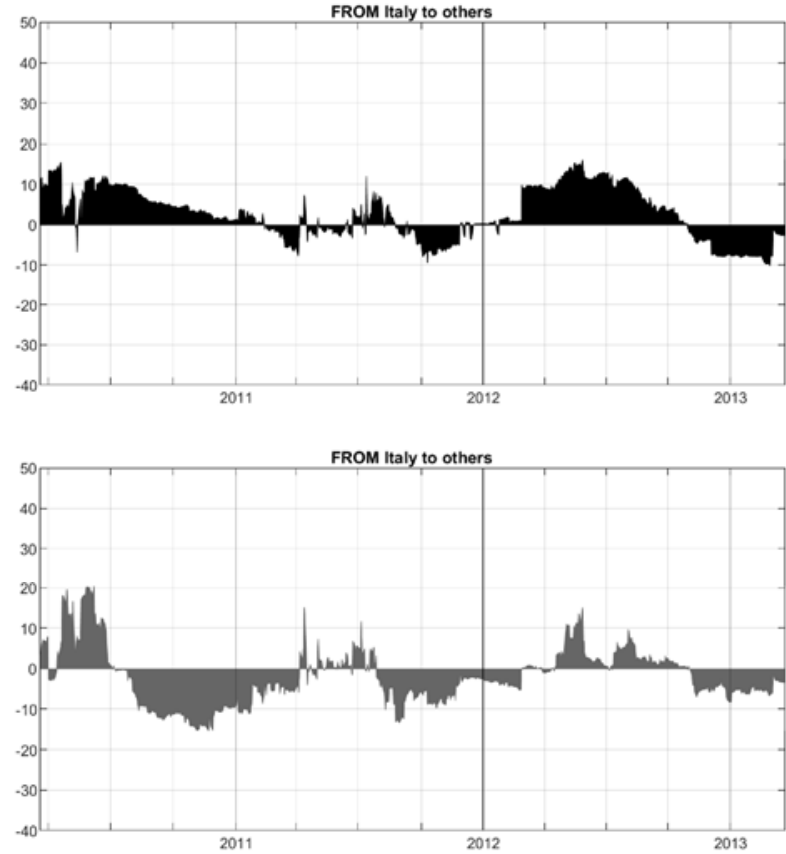

Panel D
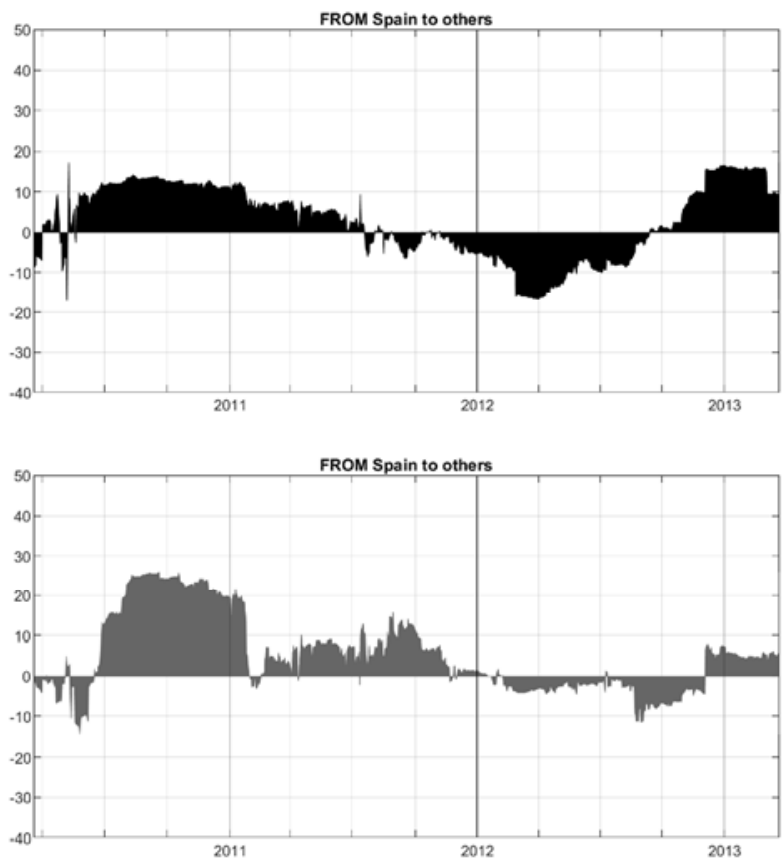
Figure 9

Net pairwise return spillover relationships (within euro-peripheral)

This figure summarizes the time evolution of the net pairwise return spillover indices for systematic contagion (in black), computed using systematic CDS returns, and idiosyncratic contagion (in grey), computed using idiosyncratic returns. They measure the net spillover due to shocks (in percentage terms) transmitted between each pair of portfolios. CDS returns for equally weighted portfolio of banks in Greece, Italy, Portugal and Spain are used. The sample period is June 2009 to March 2013.

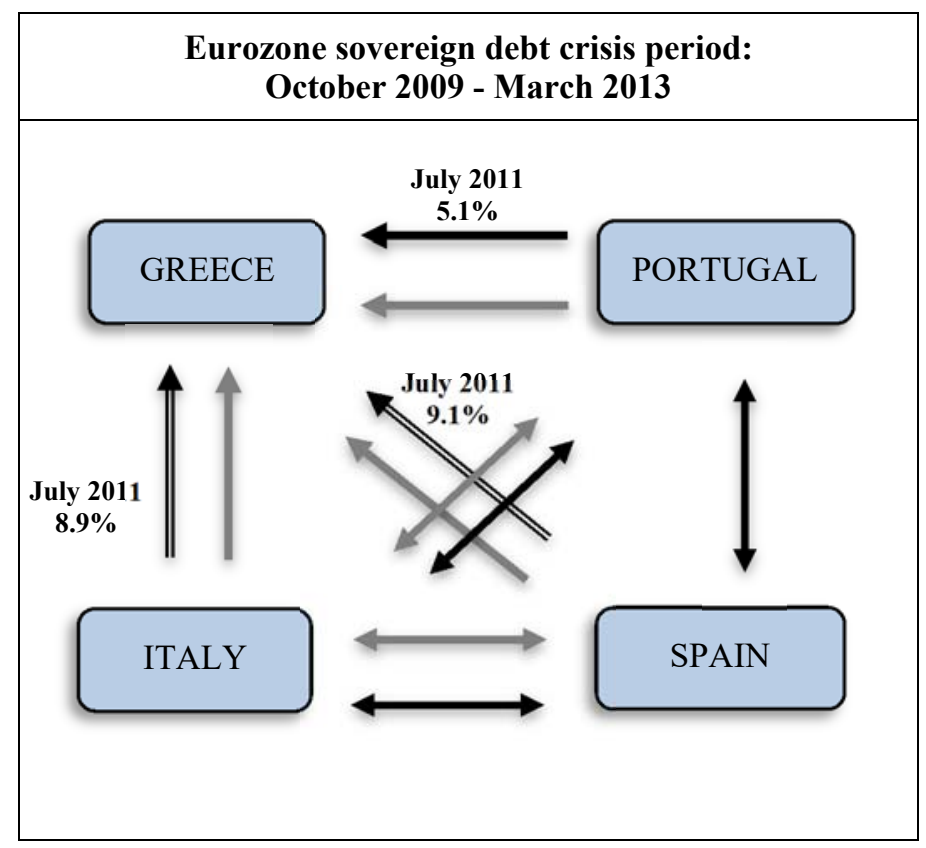

